\title{
Oridonin: A Review of Its Pharmacology, Pharmacokinetics and Toxicity
}

\author{
Xiang $\mathrm{Li}^{1,2}$, Chuan-Tao Zhang ${ }^{1,2 *}$, Wei Ma ${ }^{1,2}, \mathrm{Xin}_{\mathrm{Xie}}{ }^{1,2 *}$ and Qun Huang ${ }^{1,2 *}$ \\ ${ }^{1}$ Department of Ophthalmology, School of Pharmacy, College of Medical Technology, Hospital of Chengdu University of \\ Traditional Chinese Medicine, Chengdu University of Traditional Chinese Medicine, Chengdu, China, ${ }^{2}$ Department of Respiratory, \\ School of Pharmacy, College of Medical Technology, Hospital of Chengdu University of Traditional Chinese Medicine, Chengdu \\ University of Traditional Chinese Medicine, Chengdu, China
}

Oridonin, as a natural terpenoids found in traditional Chinese herbal medicine Isodon rubescens (Hemsl.) H. Hara, is widely present in numerous Chinese medicine preparations. The purpose of this review focuses on providing the latest and comprehensive information on the pharmacology, pharmacokinetics and toxicity of oridonin, to excavate the therapeutic potential and explore promising ways to balance toxicity and efficacy of this natural compound. Information concerning oridonin was systematically collected from the authoritative internet database of PubMed, Elsevier, Web of Science, Wiley Online Library and Europe PMC applying a combination of keywords involving "pharmacology," "pharmacokinetics," and "toxicology". New evidence shows that oridonin possesses a wide range of pharmacological properties, including anticancer, anti-inflammatory, hepatorenal activities as well as cardioprotective protective activities and so on. Although significant advancement has been witnessed in this field, some basic and intricate issues still exist such as the specific mechanism of oridonin against related diseases not being clear. Moreover, several lines of evidence indicated that oridonin may exhibit adverse effects, even toxicity under specific circumstances, which sparked intense debate and concern about security of oridonin. Based on the current progress, future research directions should emphasize on 1) investigating the interrelationship between concentration and pharmacological effects as well as toxicity, 2) reducing pharmacological toxicity, and 3) modifying the structure of oridonin-one of the pivotal approaches to strengthen pharmacological activity and bioavailability. We hope that this review can provide some inspiration for the research of oridonin in the future.

Keywords: oridonin, pharmacology, pharmacokinetics, toxicity, Isodon rubescens (Hemsl.) H.Hara

\section{INTRODUCTION}

Oridonin, (PubChem CID: 5321010, CAS No: 28957-04-2, MW: $364.4 \mathrm{~g} / \mathrm{mol}$ ), with the molecular formula of $\mathrm{C}_{20} \mathrm{H}_{28} \mathrm{O}_{6}$ (Cheng et al., 2019), is a naturally occurring terpenoids that mainly exists in Isodon rubescens (Hemsl.) H.Hara (Figure 1; Yang I.-H. et al., 2017; Jian et al., 2019; Meng et al., 2019). In thousands of years of clinical practice, the Isodon rubescens (Hemsl.) H.Hara has been widely applied as central agent in classic traditional Chinese medicine (TCM) formulas with its efficacy of clearing away heat and detoxifying, boosting blood circulation and alleviating pain. Generally, I. rubescens (Hemsl.) H.Hara is frequently utilized in the treatment of acute and chronic pharyngitis, tonsillitis and 


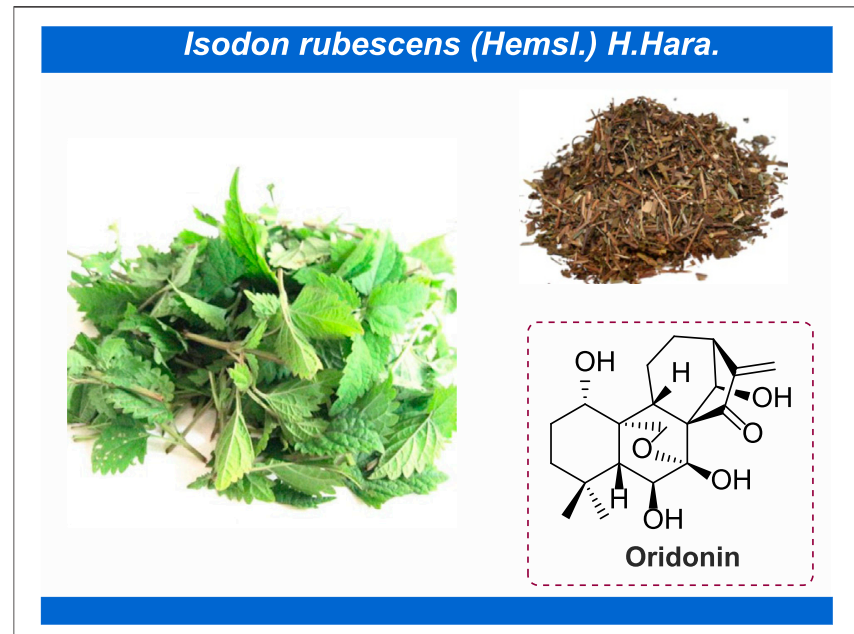

FIGURE 1 | Oridonin isolated from Isodon rubescens (Hemsl.) H.Hara.

bronchitis in clinic (Zhang et al., 2020). As the main bioactive chemical component of $I$. rubescens (Hemsl.) H.Hara, in recent years, numerous achievements have been witnessed on the exploration of pharmacological effects of oridonin, such as antiinflammatory (Cummins et al., 2019; He et al., 2019), anti-cancer (Vasaturo et al., 2018; Jeon et al., 2019; Hu et al., 2020), antimicrobial (Li D. et al., 2016), anti-sepsis (Zhao et al., 2016), neuroprotection (Lin et al., 2019), immunoregulation (Guo et al., 2013) and so on. Consequently, to some extent, these rapid advancements in the discovery of the pharmacological activity of oridonin have provided extensive opportunities for the development of innovative disease strategies. On the other hand, there have been mounting reports concentrated on the adverse reactions of oridonin. Recent studies have shown that oridonin can cause suicidal erythrocyte death, induce the expression and activation of CYP2C and CYP3A family, and interfere with the early embryonic development of zebrafish. Under this background, thereby motivated, we herein to summarize the latest and comprehensive information on the pharmacology, toxicity and pharmacokinetics of oridonin, to excavate the potential of this natural active ingredient in the treatment of various diseases and furnish basic information for the rational and secure utilization of oridonin.

\section{PHARMACOLOGY}

\section{Anti-Inflammatory Activity}

According to the literature, oridonin can markedly inhibit experimental autoimmune neuritis (EAN) by lessening local inflammatory reaction and increasing the proportion of immune regulating macrophages in the peripheral nerves possibly by the pathway of Notch, which indicates that it can be developed as a potential therapeutic agent for human GuillainBarre syndrome (GBS) and neuropathies (Xu L. et al., 2019). Moreover, the employment of oridonin enables to relieve carrageenan-induced pleurisy through activating the KEAP-1/
Nrf2 pathway and suppressing the TXNIP/NLRP3 and NF- $\kappa$ B pathway in the model of $\mathrm{BALB} / \mathrm{c}$ mice. These specific manifestations includes reducing lung injury scores, releasing of cytokines, neutrophil infiltration, exudating volume and the exudate protein concentration, decreasing the levels of oxidative stress markers (Yang et al., 2020). Recently, researcher relies on the fact that oridonin itself can act as a protective agent against LPS-induced inflammatory response, which the specific mechanisms involve in ROS accumulation, JNK activation, nuclear translocation of NF- $\kappa$ B (Huang et al., 2020). Oridonin also inhibits autophagy and survival in rheumatoid arthritis fibroblast-like synoviocytes ( $\mathrm{He}$ et al., 2020). In addition, oridonin can also resist a series of inflammatory reactions including LPS-induced inflammation in human gingival fibroblasts (Yu et al., 2019), IL-1 $\beta$-induced inflammation in human osteoarthritis chondrocytes (Jia et al., 2019) and LPSinduced endometritis (Zhou et al., 2019). These findings indicate that oridonin may be served as a potential therapeutic agent for a variety of inflammatory related diseases. A great deal of immune cells including $\mathrm{T}$ cells plays an important role in the process of inflammation. In recent years, studies on anti-inflammatory effect of oridonin based on immune response have gradually increased. Research showed that it alleviated the colitis induced by trinitrobenzene sulfonic acid as represented by a decrease in colonic interferon-/inteleukin-17 secretion and a consumption in splenic Th1/Th17 cells and effector memory CD4(+) T cells (Wang et al., 2015). In addition, oridonin inhibited inflammatory graft rejection by depleting a great number of $\mathrm{T}$ cells in spleen and peripheral blood (Guo et al., 2013).

\section{Anticancer Activity}

The efficacy of mainstay cancer therapies such as cytotoxics and radiation, has reached a plateau in the treatment of multiple cancers. In this regard, there is an urgent sense that ameliorations must now come from fresh approaches. In recent years, continuous attention is also shifting to the development of natural anti-tumor agents. Oridonin has a variety of documented anti-cancer activities such as its ability to against gastric cancer $(\mathrm{He}$ et al., 2017), oral cancer (Yang Y.-C. et al., 2017), nasopharyngeal carcinoma (Liu et al., 2021), esophageal cancer (Jiang et al., 2019), ovarian cancer (Dong et al., 2018), leukemia (Li and Ma, 2019; Zhang D. et al., 2019), and myeloma (Wu et al., 2020), etc. Its main mechanism involves in inhibiting proliferation (Hao et al., 2016), inducing apoptosis (Gu et al., 2015; Clayton et al., 2016; Qing et al., 2016; Xu et al., 2016) and autophagy (Tiwari et al., 2015; Yao et al., 2017), suppressing migration and invasion (Li Y.-C. et al., 2016), reversing drug resistance (Kadioglu et al., 2018)] and so on.

As documented in literature, utilization of oridonin increased the level of E-cadherin and ALP, reduced the vimentin, phosphoFAK levels, snail, slug, and LDH in human small cell lung cancer cell line $\mathrm{H} 1688$ with concentration of $2.5,5,10,20$, and $40 \mu \mathrm{M}$ for 24 and $48 \mathrm{~h}$ in vitro. Of course, the author also confirmed the antilung cancer effect of oridonin in the model of BALB/c nude mice (Xu et al., 2020). Another study on the anti-lung cancer of oridonin proved that, oridonin sensitized cisplatin-induced apoptosis via AMPK/Akt/mTOR-dependent autophagosome accumulation in A549 Cells (Yang et al., 2019a). Moreover, it 


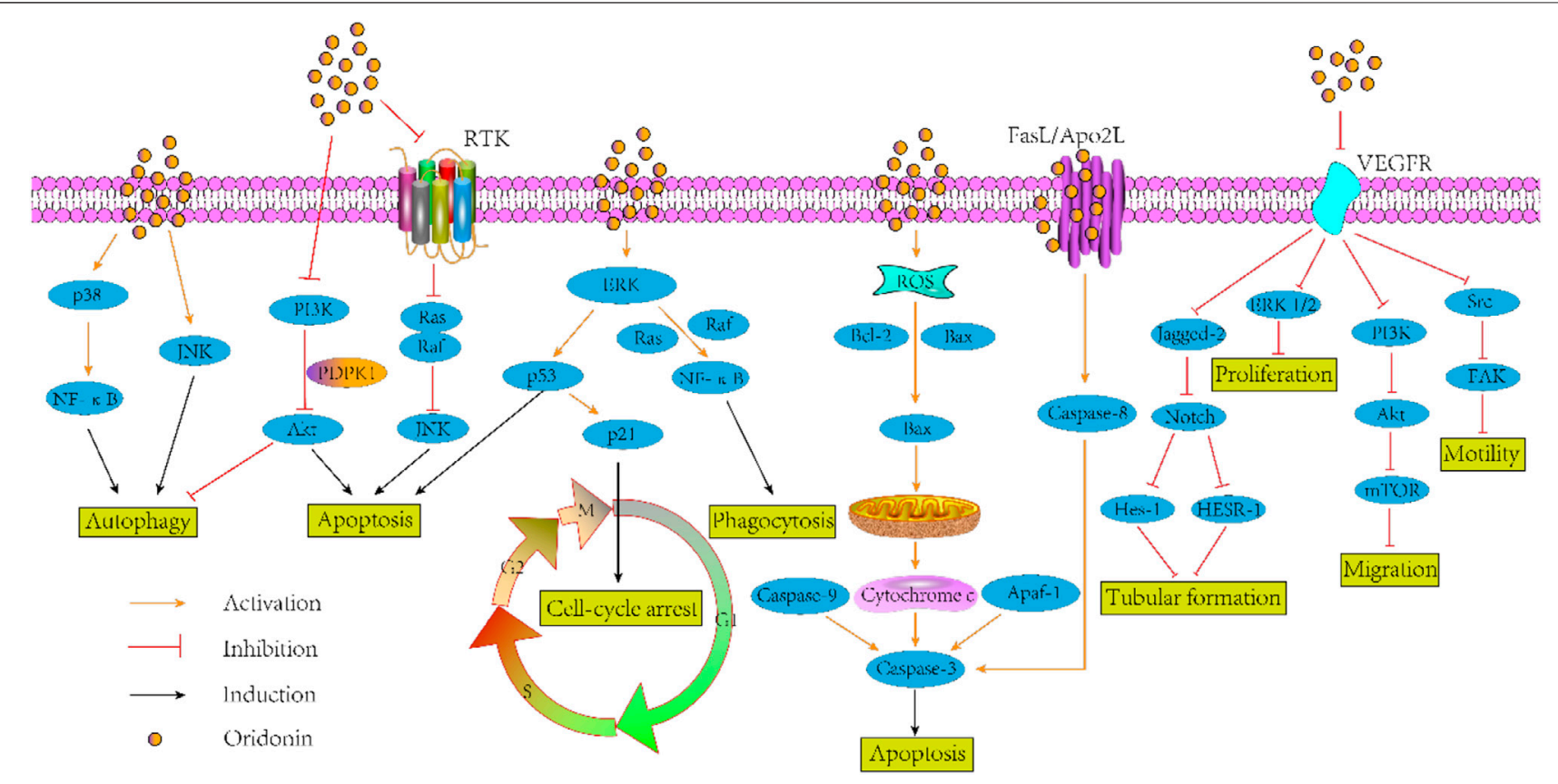

FIGURE 2 | The antitumor mechanism of oridonin.

augmented the radiosensitivity of lung cancer cells by upregulating Bax and down-regulating Bcl-2 (Li C. et al., 2018), underpinned radiation-induced cell death by accelerating DNA damage in non-small cell lung cells (Park et al., 2018) and promoted $G_{2} / M$ arrest in A549 cells by facilitating ATM (Zheng et al., 2017). In the aspect of anti-breast cancer, oridonin could synergistically enhance the anti-tumor effect of doxorubicin on aggressive breast cancer by promoting apoptosis and anti-angiogenesis (Li et al., 2019). Besides, this compound could inhibit angiogenesis and EMT related to VEGF-A (Li C. Y. et al., 2018), block Notch signaling pathway to inhibit the growth and metastasis of breast cancer (Xia et al., 2017), and induce autophagy to promote apoptosis (Li and Yang, 2015). In addition to its above anti-tumor effects, there is growing evidences that oridonin exhibits other anti-tumor activities such as colorectal cancer (Bu H. et al., 2019), pancreatic cancer (Liu D. et al., 2020), gallbladder cancer (Chen, et al., 2019), prostate cancer (Lu et al., 2017) and so on. Given that pathway defects have been recognized by most chemotherapies, oridonin may be a logical botanical for future researches of tumor adjuvant therapy. Figure 2 gives the antitumor mechanism of oridonin.

\section{Hepatorenal Protective Activity}

With the deepening of the research, the hepatorenal protective activity of oridonin has been gradually recognized. In a report on the research of LPS/D-galactosamine-induced acute liver injury in mice, oridonin was used as a compound known to be effective at improving the survival rate, alleviating histopathological abnormalities, and suppressing plasma aminotransferases, which the mechanisms may involve in the suppression of proapoptotic cytokine TNF- $\alpha$ and JNK-associated pro-apoptotic signaling (Deng et al., 2017). Oridonin also ameliorated carbon tetrachloride-induced liver fibrosis in mice through inhibiting the NLRP3 inflammasome (Liu D.-L. et al., 2020). Mouse immortalized stellate cell line JS1 treated with oridonin at the concentration of 5,10 , and $15 \mu \mathrm{M}$ showed that it significantly impede posttranslational modifications of IRAK4 in the TLR4 signaling pathway (Shi et al., 2019). In addition, the inhibition of LPS induced apoptosis promoting cytokines IL- $1 \beta$, IL-6, and MCP-1, as well as ICAM-1 and VCAM-1 observed in LX-2 cells also appear to be able to validate the protective effect of oridonin on liver (Cummins et al., 2018). In terms of kidney protection, oridonin alleviated IRI-induced kidney injury by suppressing inflammatory response of macrophages through AKT-related pathways (Yan et al., 2020). Furthermore, oridonin at the concentrations of $2.5,5,10$, and $20 \mu \mathrm{M}$ managed to alleviate albuminuria, improve renal function and attenuate renal histopathological injury, hinder inflammatory cytokine production, down-regulate TLR4 expression and inhibit NF- $\kappa \mathrm{B}$ and p38-MAPK activation, with the effects augmented as the dose increased (Li J. et al., 2018). These studies may provide a new recognition of natural medicine for the treatment of liver and kidney diseases.

\section{Cardioprotective Activity}

Diseases associated with cardiovascular diseases are an increasing problem in most parts of the world and, as with many other problems of today, are becoming more and more urgent for people all over the world. Therefore, a reasonable and effective strategy and approach is now essential to fight against this malady. As reported by researches in recent years, oridonin exhibited beneficial influences on cardiovascular disease. In a 
myocardial ischemia-reperfusion injury mouse models, downregulation of oxidative stress and NLRP 3 inflammation has been shown to mitigative effect of oridonin to myocardial ischemia reperfusion injury (Lu et al., 2020). Similar results have been verified by researchers from the perspective of metabonomics (Zhang J. et al., 2019). Oxidative stress, which has a critical link with the development of cardiac hypertrophy and heart failure, can reportedly be inhibited by oridonin via mitigating pressure overload-induced cardiac hypertrophy and fibrosis, preserving heart function, enhancing myocardial autophagy in pressureoverloaded hearts and angiotensin II-stimulated cardiomyocytes (Xu M. et al., 2019). In the respect of inhibition for vascular inflammation, oridonin could reduce the endothelial-leukocyte adhesion and leukocyte transmigration, inhibit the expression of TNF- $\alpha$-induced endothelial adhesion molecules, suppress the penetration of the leukocyte, suppress the TNF- $\alpha$-activated MAPK and Nuclear factor kappa B (NF- $\kappa \mathrm{B})$ activation, as described in the literature (Huang et al., 2018).

\section{Lung Protective Activity}

In recent years, oridonin, isolated from the plants of the genus rubescens, has shown great potential in lung protection due to its antioxidant and anti-inflammatory effects. Oxidative stress and the resulting inflammation are significant pathological processes in acute lung injury (ALI). According to the literature, oridonin can exert protective effects on LPS-induced ALI through Nrf2independent anti-inflammatory and Nrf2-dependent antioxidative activities (Yang et al., 2019b). It also protects against chemical induced pulmonary fibrosis. Research shows that it could markedly suppress the mRNA and protein expression of $\alpha$-SMA and COL1A1 in TGF-b1-induced MRC- 5 cells as well as undermine pathological changes, such as alveolar space collapse, emphysema, and infiltration of inflammatory cells induced by BLM (Fu et al., 2018). Immune regulation disorder and persistent inflammatory injury are important mechanisms of ventilatorinduced lung injury (VILI). As research has shown, oridonin can reduce VILI by blocking the interaction between NEK7 and NLRP3 and halting the activation of NLRP3 inflammatory bodies (Liu H. et al., 2020). In addition, post-exposure treatment with oridonin was able to ameliorate lung pathology, attenuate lung edema, abate MDA and TNF- $\alpha$, and elevate GSH and IL-10 in the lung, which indicate that it can defend the lung against hyperoxia-induced injury in the model of mice (Liu et al., 2017).

\section{Neuroprotective Activity}

Oridonin produced a conspicuous effect of neuroprotective in PC12 and N2a cells by rescuing IR, reducing the autophagosome formation and synaptic loss and ameliorating cognitive dysfunction, halting IRinduced synaptic deficits (Wen et al., 2020). In the $A \beta_{1-42}$-induced mouse model of Alzheimer's disease (AD), oridonin sharply rescues synaptic loss induced by $\mathrm{A} \beta_{1-42}$, lessens the alterations in dendritic structure and spine density, augment PSD-95 and promotes mitochondrial activity (Wang J. et al., 2016). The neuropathological characteristics of $\mathrm{AD}$ are amyloid aggregation, tau phosphorylation, and neuroinflammation. A study indicates that different routes of administration of oridonin severely attenuated-amyloid deposition, plaque-associated APP expression and microglial activation, which suggest that this natural terpenoid might be considered a prospective therapeutic agent for human neurodegenerative diseases such as AD (Zhang et al., 2013). Furthermore, available data suggest the potentiality of oridonin to attenuate $\mathrm{A} \beta_{1-42}$-induced neuroinflammation and inhibit NF- $\kappa \mathrm{B}$ pathway (Wang et al., 2014).

\section{Other Pharmacological Activities}

Several lines of evidence suggest oridonin exerts its potential role of amelioration lupus-like symptoms through suppressing BAFF expression, improving serological and clinical manifestations of SLE, lessening proteinuria levels, diminishing production of specific auto-antibodies (Zhou et al., 2013). Besides, oridonin exerted its protective effects against hydrogen peroxide-induced damage by altering the profiles of mRNA in human dermal fibroblasts (Lee et al., 2013). In the treatment of respiratory diseases, oridonin could lessen protein quantification in bronchoalveolar lavage fluid and the lung W/D ratio, mitigate inflammation and suppress the injuries, as well as abate the TNF- $\alpha$, IL-6 (Jiang et al., 2017). Oridonin could also decrease the OVA-induced airway hyper-responsiveness and eosinophil number, and suppress the eosinophilia and mucus production, which confirms its great prospect in the treatment of asthma (Wang S. et al., 2016). In addition, oridonin could effectively ameliorate inflammation-induced bone loss in the model of mice by inhibiting DC-STAMP expression (Zou et al., 2020), halt the growth of methicillin-resistant Staphylococcus aureus (MRSA) (Yuan et al., 2019), mitigate visceral hyperalgesia in a rat model of postinflammatory irritable bowel syndrome (Zang et al., 2016), and augment gamma-globin expression in erythroid precursors from patients (Guo et al., 2020).

Due to the extensive biological effects of oridonin, its application in aquaculture has been gradually discovered in recent years. As reported in the literature, oridonin could improve the antioxidant capacity of arbor acres broilers liver, as evidenced by the decrease in MDA and the increase in total SOD activities and mRNA expression levels of the liver antioxidant genes (Zheng, et al., 2016). Adding oridonin to the diet of arbor acres broilers could significantly improve the immune response induced by Salmonella and protect the intestinal health (Wu et al., 2018a), increase the relative weights of spleen and bursa, number of proliferation peripheral blood $\mathrm{T}$ and $\mathrm{B}$ lymphocytes, the phagocytic rate of neutrophils, as well as the IL-2, IL-4, and TNF- $\alpha$ (Wu et al., 2018a). In addition, oridonin could also interfere with the effects of Salmonella pullorum on immune cells and Th1/Th2 balance of spleen in arbor acres broilers (Wu et al., 2018b). As discussed above, oridonin is a natural active compound with therapeutic potential for dozens of diseases. Additional details on the pharmacological activities of oridonin were depicted as in Table $\mathbf{1 .}$

\section{PHARMACOKINETICS}

In the process of innovative agent development, pharmacokinetic research has become a pivotal part of preclinical and clinical research of drugs. It not only plays a supporting role in drug toxicity or clinical research, but also contributes to optimize the 
TABLE 1 | Pharmacology of oridonin.

\begin{tabular}{|c|c|c|c|c|c|}
\hline Pharmacological effects & Detail & Cell lines/Model & Dose & Application & Ref \\
\hline \multirow[t]{11}{*}{ Anti-inflammatory activity } & $\begin{array}{l}\text { Reduce lung injury scores, cytokines, neutrophil infiltration, and exudate volume and exudate protein } \\
\text { concentration, decrease oxidative stress markers }\end{array}$ & $\mathrm{BALB} / \mathrm{c}$ mice & $5-20 \mathrm{mg} / \mathrm{kg}$ & In vivo & Yang et al. (2020) \\
\hline & Prevent ROS accumulation, attenuate RAW 264.7 cell chemotaxis toward LPS-treated HK-2 cells & $\begin{array}{l}\text { HK-2 cells } \\
\text { RAW } 264.7\end{array}$ & $\begin{array}{l}30 \mu \mathrm{\mu g} / \mathrm{ml} \\
30 \mu \mathrm{gg} / \mathrm{ml}\end{array}$ & $\begin{array}{l}\text { In vitro } \\
\text { In vitro }\end{array}$ & Huang et al. (2020) \\
\hline & \multirow{3}{*}{$\begin{array}{l}\text { Suppress proliferation, increase apoptosis and Bax and cleaved caspase- } 3 \text { but decrease the IL-1b, inhibit ATG5 and Beclin1 } \\
\text { Inhibit inflammatory mediators PGE2, NO, IL-6, and IL-8, reduce phosphorylation of NF- } k \text { B p65 and IkB } \alpha \text {, up-regulate PPAR- } \gamma \\
\text { Suppress IL-1 } \beta \text {-induced MMP1, MMP3, and MMP13, attenuate IL-1 } 1 \beta \text {-induced NO and PGE2, as well as iNOS and COX-2, reduce } \\
\text { IL-1 } \beta \text {-induced NF- } k B \text { activation }\end{array}$} & RA-FLSS & $2-12 \mu \mathrm{g} / \mathrm{ml}$ & In vitro & He et al. (2020) \\
\hline & & Human gingival fibroblasts & $10-30 \mu \mathrm{g} / \mathrm{ml}$ & In vitro & Yu et al. (2019) \\
\hline & & Human chondrocytes & $10-30 \mu \mathrm{g} / \mathrm{ml}$ & In vitro & Jia et al. (2019) \\
\hline & $\begin{array}{l}\text { Alleviate LPS-induced endometritis and reduce the activity of myeloperoxidase, decrease TNF- } \alpha \text {, IL-1 } 1 \beta \text {, and IL-6, inhibit LPS- } \\
\text { induced TLR4/NF- } k \text { B signaling pathway activation }\end{array}$ & $\begin{array}{l}\text { BALB/c mice } \\
\text { mEECs }\end{array}$ & $\begin{array}{l}40 \mathrm{mg} / \mathrm{kg} \\
10-100 \mathrm{\mu g} / \mathrm{ml}\end{array}$ & $\begin{array}{l}\text { In vivo } \\
\text { In vitro }\end{array}$ & Zhou et al. (2019) \\
\hline & \multirow{3}{*}{$\begin{array}{l}\text { Relieve hypoxia-evoked apoptosis and autophagy via modulating microRNA-214 } \\
\text { Inhibit pro-inflammatory cytokines, such as IL-1 } 1 \beta \text {, LL-6, and TNF- } \alpha \text {, through the TLR4/MyD88/NF- } \kappa \text { B axis }\end{array}$} & H9c2 cells & $\begin{array}{l}10-100 \mu \mathrm{\mu g} / \mathrm{ml} \\
1-20 \mu \mathrm{M}\end{array}$ & $\begin{array}{l}\text { In vitro } \\
\text { In vitro }\end{array}$ & Gong et al. (2019) \\
\hline & & BALB/c mice & $10-40 \mathrm{mg} / \mathrm{kg}$ & In vivo & Zhao G. et al. (2017) \\
\hline & & RAW264.7 cells & $5-40 \mu \mathrm{g} / \mathrm{ml}$ & In vitro & \\
\hline & Inhibits IL-1 $\beta$-induced proliferation and phosphorylation of MAPK, promote apoptosis and increase intracellular ROS. & Primary human FLSs & $5-40 \mu \mathrm{M}$ & In vitro & Shang et al. (2016) \\
\hline & Protect HaCaT keratinocytes against hydrogen peroxide-induced oxidative stress by altering microRNA expression & HaCaT keratinocytes & $1-20 \mu \mathrm{M}$ & In vitro & Bae et al. (2014) \\
\hline \multirow[t]{39}{*}{ Anticancer activity } & Increase the level of E-cadherin and ALP, reduce the vimentin, phospho-FAK levels, & H1688 cells & $2.5-40 \mu \mathrm{M}$ & In vitro & Xu et al. (2020) \\
\hline & \multirow[t]{3}{*}{ snail, slug, and LDH, and inhibit tumor growth in mouse model } & BEAS-2B cells & $2.5-40 \mu \mathrm{M}$ & In vitro & \\
\hline & & HBE cells & $2.5-40 \mu \mathrm{M}$ & In vitro & \\
\hline & & BALB/c mice & $5-10 \mathrm{mg} / \mathrm{kg}$ & In vivo & \\
\hline & \multirow[t]{3}{*}{ Enhance cisplatin sensitivity via pro-apoptotic activity mediated by AMPK/Akt/mTOR-dependent autophagosome activation } & A549 cells & 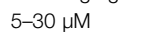 & In vitro & Yang et al. (2019a) \\
\hline & & B2b cells & 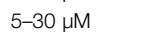 & In vitro & \\
\hline & & C57BL/6 WT mice & $20 \mathrm{mg} / \mathrm{kg}$ & In vivo & \\
\hline & \multirow{2}{*}{$\begin{array}{l}\text { Inhibit the proliferation in a time- and dose-dependent manner, enhance the radiosensitivity of SPC-A-1 cells, increase Bax and } \\
\text { decrease the Bcl-2 }\end{array}$} & HCC827 cells & $10-80 \mu \mathrm{M}$ & In vitro & Li C. et al. (2018) \\
\hline & & SPC-A-1 cells & $10-80 \mu \mathrm{M}$ & In vitro & \\
\hline & \multirow{2}{*}{$\begin{array}{l}\text { Enhance radiation-induced inhibition of cell growth and clonogenic survival, facilitate radiation-induced ROS production and DNA } \\
\text { damage and enhance apoptotic cell death }\end{array}$} & $\mathrm{NCl}-\mathrm{H} 460$ cells & $1-5 \mu \mathrm{M}$ & In vitro & Park et al. (2018) \\
\hline & & BALB/c mice & $15 \mathrm{mg} / \mathrm{kg}$ & In vivo & \\
\hline & Inhibit proliferation by inducing cycle arrest at G2/M through ATM-p53-CHK2 pathway & A549 cells & $16-64 \mu \mathrm{M}$ & In vitro & Zheng et al. (2017) \\
\hline & \multirow{3}{*}{$\begin{array}{l}\text { Increase the intracellular accumulation of Dox, decrease proliferation, migration, invasion and tube formation, reverse Dox-induced } \\
\text { cardiotoxicity }\end{array}$} & MDA-MB-231 cells & $0.6-20 \mu \mathrm{M}$ & In vitro & Li et al. (2019) \\
\hline & & HUVECs cells & $2.5 \mu \mathrm{M}$ & In vitro & \\
\hline & & BALB/c nude mice & $16 \mathrm{mg} / \mathrm{kg}$ & In vivo & \\
\hline & Suppress migration, invasion and adhesion, inhibit tube formation and EMT, decrease & BALB/c mice & $2.5-10 \mathrm{mg} / \mathrm{kg}$ & In vivo & Li C. Y. et al. (2018) \\
\hline & \multirow{2}{*}{$\mathrm{N}$-cadherin, Vimentin and Snail, HIF-1 $\alpha$, VEGF-A and VEGF receptor-2 protein expression } & MDA-MB-231 cells & $2-64 \mu \mathrm{M}$ & In vitro & \\
\hline & & MCF-10A cells & $2-64 \mu \mathrm{M}$ & In vitro & \\
\hline & Induce cells apoptosis, inhibit cancer cell migration and invasion, & $4 \mathrm{~T} 1$ cells & $0.1-10 \mathrm{mM}$ & In vitro & Xia et al. (2017) \\
\hline & and decrease the expression of Notch $1-4$ protein & BALB/C athymic mice & $10-20 \mathrm{mg} / \mathrm{kg}$ & In vivo & \\
\hline & \multirow[t]{2}{*}{ Inhibit proliferation, induce apoptosis, up-regulate Bax and down-regulate Bcl-2, increase cleaved caspase-9 and LC3-II. } & MDA-MB-436 cells & $10-80 \mu \mathrm{M}$ & In vitro & Li et al. (2015) \\
\hline & & MDA-MB-231 cells & $10-80 \mu \mathrm{M}$ & In vitro & \\
\hline & \multirow{5}{*}{$\begin{array}{l}\text { Inhibit proliferation and induce apoptosis, reduce } \beta \text {-catenin, increase GSK3 } 3 \text { and decrease phosphorylation of GSK } 3 \beta \text {, suppress } \\
\text { tumor growth } \\
\text { Inhibit proliferation, induce cellular morphology changes and Bax translocation from cytosolic to mitochondrial compartments, and } \\
\text { suppress tumor growth }\end{array}$} & COLO205 cells & $5-25 \mu \mathrm{M}$ & In vitro & Bu H. et al. (2019) \\
\hline & & BALB/c nude mice & $10-20 \mathrm{mg} / \mathrm{kg}$ & In vivo & \\
\hline & & BXPC-3 cells & 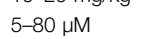 & In vitro & Liu D. et al. (2020) \\
\hline & & PANC-1 cells & 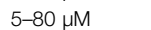 & In vitro & \\
\hline & & BALB/c nude mice & $40 \mathrm{mg} / \mathrm{kg}$ & In vivo & \\
\hline & \multirow[t]{2}{*}{ Suppress proliferation, induce apoptosis and cell cycle arrest at the $G_{0} / G_{1}$ phase, down-regulate $H I F-1 \alpha / M M P-9$} & GBC-SD cells & $5-20 \mu \mathrm{M}$ & In vitro & Chen et al. (2019) \\
\hline & & BALB/c nude mice & $15 \mathrm{mg} / \mathrm{kg}$ & In vivo & \\
\hline & \multirow{2}{*}{$\begin{array}{l}\text { Inhibit proliferation and induce G2/M cell cycle arrest and apoptosis, up-regulate p53, p21, proteolytic cleaved forms of caspase-3, } \\
\text { caspase-9, decrease B-cell lymphoma } 2\end{array}$} & PC3 cells & $20-60 \mu \mathrm{M}$ & In vitro & Lu et al. (2017) \\
\hline & & DU145 cells & $20-60 \mu \mathrm{M}$ & In vitro & \\
\hline & \multirow{3}{*}{$\begin{array}{l}\text { Inhibit proliferation, invasion, and migration, down-regulate phosphorylation of EGFR, ERK, Akt, expression of MMP-12 and } \\
\text { CIP2A, inhibit tumor growth in vivo }\end{array}$} & A549 cells & $40-90 \mu \mathrm{M}$ & In vitro & Xiao et al. (2016) \\
\hline & & $\mathrm{NCl}-\mathrm{H} 1975$ cells & 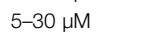 & In vitro & \\
\hline & & Nude mice & $30 \mathrm{mg} / \mathrm{kg}$ & In vivo & \\
\hline & \multirow{3}{*}{ Elevate cisplatin-caused reduction of cell viabilities and enhance cell apoptosis, inhibit autophagy } & A2780CP cells & $5-40 \mu \mathrm{M}$ & In vitro & Zhao and Xia, (2019) \\
\hline & & SKOV 3 cells & $5-30 \mu \mathrm{M}$ & In vitro & \\
\hline & & DDP cells & 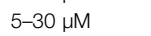 & In vitro & \\
\hline & \multirow[t]{2}{*}{ Suppress the proliferation and block the cell cycle in $\mathrm{G} 1 / \mathrm{S}$ phage and induce apoptosis } & SKOV3 cells & 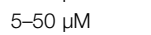 & In vitro & Wang et al. (2019) \\
\hline & & & & & \\
\hline
\end{tabular}

Enhance radiation-induced inhibition of cell growth and clonogenic survival, facilitate radiation-induced ROS production and DNA

Increase the intracellular accumulation of Dox, decrease proliferation, migration, invasion and tube formation, reverse Dox-induced

Suppress migration, invasion and adhesion, inhibit tube formation and EMT, decrease

and decrease the expression of Notch 1-4 protein

Inhibit proliferation and induce apoptosis, reduce $\beta$-catenin, increase GSK3 $\beta$ and decrease phosphorylation of GSK3 $\beta$, suppress

suppress tumor growt

Inhibit proliferation and induce G2/M cell cycle arrest and apoptosis, up-regulate p53, p21, proteolytic cleaved forms of caspase-3, Inhibit proliferation, invasion, and migration, down-regulate phosphorylation of EGFR, ERK, Akt, expression of MMP-12 and $2 \mathrm{~A}$, inhibit tumor growth in vivo

Suppress the proliferation and block the cell cycle in $\mathrm{G} 1 / \mathrm{S}$ phage and induce apoptosis

DDP cells 
1Reverse cisplatin resistance, induce apoptosis and promote cell-cycle arrest, down-regulate Bcl-2 and up-regulate Bax protein, A2780 cells decrease MMP-2 and MMP-9

A2780 cells
SKOV 3 cells

Induce ROS accumulation and cell apoptosis via the c-Jun N-terminal kinase (JNK)/c-Jun pathway

DLD1 cells

RKO cells

LS174T cells

SW480 cells

SW48 cells

HCT116 cells

HCT-15 cells

Inhibit proliferation, reduce Smad2, Smad3, Smad4, PAl-1 and the phosphorylation

LOVO cells

of Smad2 and Smad3 induced by TGF- $\beta 1$ in vitro and suppress tumor growth in vivo

SW480 cells

HT29 cells

BALB/c nude mice

Inhibit proliferation and induce apoptosis, increase total and phosphorylated levels

HCT116 cells

SW620 cells

of $p 53$, increase the expression of BMP7, reduce the growth rate of tumors in mice

SW620 cells

SW480 cells

LoVo cells

FHC cells

Inhibit the proliferation and induce the apoptosis, up-regulate BMP7 and increase the level of phosphorylated p38 MAPK.

reduce the phosphorylation of PTEN.

Inhibit proliferation, induce apoptosis, arrest cell cycle, prevent migration, regulate EMT-related protein expression, and inhibit cel

HCT116 cells

tumorigenicity and EMT in nude mice

Athymic nude mice

Lead to a dose-dependent reduction of clonogenic survival and an increase in $\gamma \mathrm{H} 2 \mathrm{AX}$, observe additive effects and a prolonged PANC-1 cells

BALB/C nude mice

G2/M-arres

AsPC-1 cells

MIA PaCa-2 cells

Inhibit proliferation, downregulate miR-200b-3p, inhibit migration, EMT and ZEB1, N-cadherin and fibronectin. In vivo, inhibit migration in the nude mouse model

Overcome PANC-1/Gem cells gemcitabine reistance by regulating GST pi and LRP1/ERK/JNK signaling

BXPC-3 cells

PANC-1 cells

BALB/C nude mice

PANC-1 cells

PANC-1/Gem cells

Inhibit proliferation and potentiate gemcitabine-induced apoptosis, up-regulate the pro-apoptotic genes Bax, cytochrome c (cyt c), PANC-1 cells and caspase- 3 and-9

105 mRNAs were differentially expressed

Cause a perturbation in mitochondrial redox status

Increase the anticancer effects

BxPC-3 cells

HepG2 cells

L02 cells

HepG2 cells

Increase the inhibitory effect on tumor cells and induce apoptosis

SMMC-7721 cells

Induce apoptosis and regulate expression and activity of apoptosis-related proteins, down-regulate nuclear translocation of p50 HepG2 cells

and p65, decrease the transcription activity of all NF-kappa B subunits

Induce tumor cell necroptosis by reducing GSH and enhancing ROS formation, enhance cytotoxic effect of 5-FU.

$786-0$ cells

Nude mice

HGC-27 cells

Suppress cell viability and inhibit cell proliferation by inducing G2/M arrest, induce caspase-dependent apoptosis

Inhibit proliferation, migration, and survivability, enhance apoptosis and the anti-tumor effect of cisplatin, up-regulate mRNA and protein expression of $\mathrm{p} 53$

Inhibit proliferation, induce apoptosis, down-regulate Bcl-2 and up-regulate Bax, induce the release of cytochrome

SGC-7901 cell

Inhibit P300, GCN5, Tip60, and PCAF, inhibit proliferation and down-regulate p53, induce

apoptosis, increase activated caspase-3 and caspase-9, decrease the mitochondrial membrane potentia

$5-50 \mu \mathrm{M}$

10-160 In vitro

$10-160 \mu \mathrm{MM}-\quad$ In vitro

10-160 $\mu \mathrm{MM} \quad$ In vitro

$10-90 \mu \mathrm{M} \quad$ In vitro

10-90 $\mu \mathrm{M} \quad$ In vitro

10-90 $\mu \mathrm{M} \quad$ In vitro

10-90 $\mu \mathrm{M} \quad$ In vitro

10-90 $\mu \mathrm{M} \quad$ In vitro

$10-90 \mu \mathrm{M} \quad$ In vitro

$2-16 \mu \mathrm{g} / \mathrm{ml} \quad$ In vitro

$2-16 \mu \mathrm{g} / \mathrm{ml} \quad$ In vitro

$2-16 \mu \mathrm{g} / \mathrm{ml} \quad$ In vitro

$2.5,5,7.5 \mathrm{mg} /$ In vivo

$\mathrm{kg}$

5-25 $\mu \mathrm{M} \quad$ In vitro

$5-25 \mu \mathrm{M} \quad$ In vitro

5-25 $\mu \mathrm{M} \quad$ In vitro

$5-25 \mu \mathrm{M} \quad$ In vitro

$5-25 \mu \mathrm{M} \quad$ In vitro

50-100 mg/kg In vivo

$\begin{array}{ll}5-25 \mu \mathrm{M} & \text { In vitro } \\ 5-80 \mu \mathrm{M} & \text { In vitro }\end{array}$

$5-80 \mu \mathrm{M} \quad$ In vitro

$\begin{array}{ll}50-100 \mathrm{mg} / \mathrm{kg} & \text { In vivo } \\ 20-160 \mu \mathrm{M} & \text { In vitro }\end{array}$

20-160 $\mu \mathrm{M} \quad$ In vitro

$10 \mathrm{mg} / \mathrm{kg} \quad$ In vivo

$0.5-2.5 \mu \mathrm{g} / \mathrm{ml} \quad$ In vitro

$0.5-2.5 \mu \mathrm{g} / \mathrm{ml} \quad$ In vitro

$0.5-2.5 \mathrm{\mu g} / \mathrm{ml} \quad$ In vitro

20-160 MM In vitro

20-160 $\mu \mathrm{M} \quad$ In vitro

$10 \mathrm{mg} / \mathrm{kg} \quad$ In vivo

10-160 MM In vitro

$\begin{array}{ll}10-160 \mu \mathrm{M} & \text { In vitro } \\ \text { 20-100 } \mu \mathrm{M} & \text { In vitro }\end{array}$

In vitro

$5-60 \mu \mathrm{M}$

$4-40 \mu \mathrm{M}$

$4-40 \mu \mathrm{M}$

4-40 $\mu \mathrm{M}$

$0.5-50 \mu \mathrm{g} / \mathrm{ml}$

Ma S. et al. (2016)

Zhang D. et al. (2019)

Bu H.-Q. et al. (2019)

Liu R.-X. et al. (2018)

Ren et al. (2016)

Wu et al. (2016)

Lou et al. (2019)

Liermann et al. (2017)

Gui et al. (2017)

Wang and Zhu (2019)

Liu et al. (2014)

Gui et al. (2015)

Liu X. et al. (2018)

In vitro

In vitro

In vitro

In vitro

10-40 $\mu \mathrm{M}$

In vitro

$20 \mathrm{mg} / \mathrm{kg}$

$2.5-15 \mu \mathrm{M}$

In vitro

Dong et al. $(2016$

Zheng et al. (2018)

$10-80 \mu \mathrm{M}$

$2-8 \mu \mathrm{M}$

$1-100 \mu \mathrm{M}$

In vitro

Ren et al. (2020)

Bi et al. (2018)

Gao et al. (2016)

Shi et al. (2016)

(Continued on following page 
TABLE 1 | (Continued) Pharmacology of oridonin.

Suppress proliferation and soft agar colony formation, induce ROS-dependent apoptosis by mitochondrial-dependent pathway HN22 cells Enhance the mitochondrial apoptosis through NF- $k \mathrm{~B}$, induce ROS production

Result in apoptoss and induce alo Tu212 cells

Thep-2 cells
Tu212 cells

Target caspase-9 to alter ROS production and autophagy to promote cell apoptosis

Induce ROS-mediated cell apoptosis

Tu212 cells

Induce apoptosis, increase the t-Bid as a downstream target of MCL-1 and decrease mitochondrial membrane potential $\quad$ MC-3 cells

Exhibit anti-RUNX1-ETO activity, and ERK2 kinase inhibitors, cause decrease of phosphorylated ERK1/2

YD-15 cells

Kasumi-1 cells

U937 cells

Jurkat cells

Inhibit EMT, prevent TGF- $\beta 1$-induced EMT by inhibiting Smad2/3 pathway and osteosarcoma metastasis to lung in the metastatic MG-63 cells model

$143 \mathrm{~B}$ cells

$\mathrm{U}-2 \mathrm{OS}$ cells

Inhibit expression of protein that related to cell proliferation

Exert its anticancer activity partially by targeting the Mdm2-p53 axis in NB cells

Nude mice

LP-1 cells

SH-SY5Y cells

SK-N-SH cells

Suppress proliferation, induce apoptosis, downregulates the $\mathrm{Wnt} / \beta$-catenin signaling pathway

SK-N-MC cells

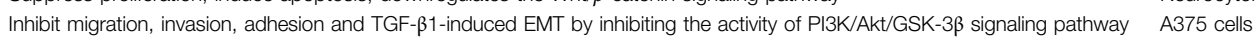

Down-regulate VEGFR2-mediated FAK/MMPs, mTOR/PI3K/Akt and ERK/p38 signaling pathways

A375 cells

Inhibit proliferation, migration, invasion, and tube formation and induce apoptosis,

HUVECS

decrease VEGFA, VEGFR2, and VEGFR3 expressions, while increase the TP53

Hepatorenal protective activity Attenuate liver injury and reduce ALT levels, Sirius Red staining and the $\alpha$-SMA, downregulate NLRP3, caspase-1, and IL-1 $\beta$ and C57BL/6J mice

decrease the expression of $\mathrm{F} 4 / 80$

HUVECS

Inhibit proinfammatory cytokines IL1-beta, LL-6, MCP-1, cell adhesion molecules ICAM-1 and VCAM-1, block LPS-induced NF- $k B \quad$ LX-2 cells

p65 nuclear translocation and DNA binding activity

Alleviate albuminuria, improve renal function and attenuate histopathological injury, decrease inflammatory cytokine, down-

regulate TLR4 and inhibit NF- $\kappa$ B and p38-MAPK activation

SD rats

Inhibit LX-2 and HSC-T6 proliferation, induce apoptosis and S phase arrest, decrease $\alpha$-SMA and ECM protein type I collagen and

Rat mesangial cell

fibronectin, block TGF- $\beta 1$-induced Smad2/3 phosphorylation and type I Collagen expression

Cardioprotective activity

Alleviate myocardial injury induced via inhibiting the oxidative stress and NLRP3 inflammasome pathway

LX-2 cells

Decrease infarct size and reverse abnormal elevated my

C57BL6 mice

Mitigate pressure overload-induced cardiac hypertrophy and fibrosis, preserve heart function, and enhance myocardial autophagy

NRCMs

Reduce endothelial-leukocyte adhesion and leukocyte transmigration, inhibit TNF- $\alpha$-induced endothelial adhesion molecules, suppress penetration of the leukocyte, and suppress TNF- $a$-activated MAPK and NF-kB activation

C57BL/6 mice

HUVECS

Lung protective activity

Increase Nrf2 and HO-1, GCLM, inhibit LPS-induced activation of the pro-inflammatory pathways NLRP3 inflammasome and NF$\kappa \mathrm{B}$ pathways

Inhibit myofibroblast differentiation and bleomycin-induced pulmonary fibrosis by regulating TGF-beta/smad pathway

C57BL/6 mice

Kunming mice

MRC-5 cells

Rescue IR, reduce the autophagosome formation and synaptic loss

and improve cognitive dysfunction, block IR-induced synaptic deficits

$\mathrm{SD}$ rats

PC12 cells

N2a cell

Rescue synaptic loss induced by $A \beta_{1-42}$, attenuate alterations in

C57BL/6 (B6) mice

dendritic structure and spine density, increase PSD-95 and synaptophysin

APP/PS1-21 mice

5-10

12-36 $\mu$

12-36 $\mu \mathrm{M}$

$24 \mu \mathrm{M}$

$24 \mu \mathrm{M}$

$36 \mu \mathrm{M}$

$10-50 \mu \mathrm{M}$

7.5-30 $\mu \mathrm{M}$

$7.5-30 \mu \mathrm{M}$
$6.25-25 \mu \mathrm{M}$

$6.25-25 \mu \mathrm{M}$
$1-5 \mu \mathrm{M}$
$1-5 \mu \mathrm{M}$

$1-5 \mu \mathrm{M}$

$0.5-2 \mu \mathrm{M}$

$0.5-2 \mu \mathrm{M}$

$0.5-2 \mu \mathrm{M}$

$15 \mathrm{mg} / \mathrm{kg}$

5-50 $\mu \mathrm{M}$

$2-20 \mu \mathrm{M}$

$2-20 \mu \mathrm{M}$

$2-20 \mu \mathrm{M}$

$5-25 \mu \mathrm{M}$

5-40 $\mu \mathrm{M}$

$5-40 \mu \mathrm{M}$

$5-40 \mu \mathrm{M}$
$2.5-20 \mu \mathrm{M}$

$39-312 \mu \mathrm{g} / \mathrm{ml}$

$39-312 \mu \mathrm{\mu g} / \mathrm{ml}$

$50-200 \mu \mathrm{g} / \mathrm{m}$

$5 \mathrm{mg} / \mathrm{kg}$

$1.25 \mu \mathrm{M}$

2.5-7.5 $\mu \mathrm{M}$

$10 \mathrm{mg} / \mathrm{kg}$

2.5-20 HM

2.5-30 $\mu \mathrm{M}$

2.5-30 $\mu \mathrm{M}$

$10 \mathrm{mg} / \mathrm{kg}$

$10 \mathrm{mg} / \mathrm{kg}$

$5-50 \mu \mathrm{M}$

$40 \mathrm{mg} / \mathrm{kg}$

$35 \mathrm{mg} / \mathrm{kg}$

$35 \mathrm{mg} / \mathrm{kg}$

$20-40 \mathrm{mg} / \mathrm{kg}$
$2.5-10 \mu \mathrm{M}$

$2.5-10 \mathrm{pM}$

$10-20 \mathrm{mg} / \mathrm{kg}$
$2.5-20 \mu \mathrm{M}$

$5 \mathrm{mg} / \mathrm{kg}$

$0.05-5 \mu \mathrm{M}$

$0.05-5 \mu \mathrm{M}$

$10-50 \mathrm{mg} / \mathrm{kg}$

Application

Ref

$\begin{array}{ll}\text { In vitro } & \text { Oh et al. (2018) } \\ \text { In vitro } & \text { Kang et al. (2020) }\end{array}$

In vitro Cao et al. (2019)

In vitro

Kang et al. (2015)

In vitro Pi et al. (2015)

Han et al. (2020)

in vitro

In vitro

In vitro

In vitro

In vitro

In vivo

In vivo

In vitro

In vitro Liang et al. (2018)

In vitro

In vitro

in vivo

In vitro

In vitro

In vitro

In vivo

In vitro

In vitro

In vitro

In vivo

In vivo

Li J. et al. (2018)

Jiang et al. (2020)

Tian et al. (2017)

Liu D.-L. et al. (2020)

Shi et al. (2019)

Cummins et al.

(2018)

Li S. et al. (2018)

Bohanon et al. (2014)

Lu et al. (2020)

Zhang W. et a.

(2019)

In vitro

Xu L. et al. (2019)

Huang et al. (2018)

Yang et al. (2019b)

Fu et al. (2018)

Wen et al. (2020)

Wang J. et al. (2016)

$20 \mathrm{mg} / \mathrm{kg}$

In vivo

Zhang et al. (2013)

Continued on following page) 


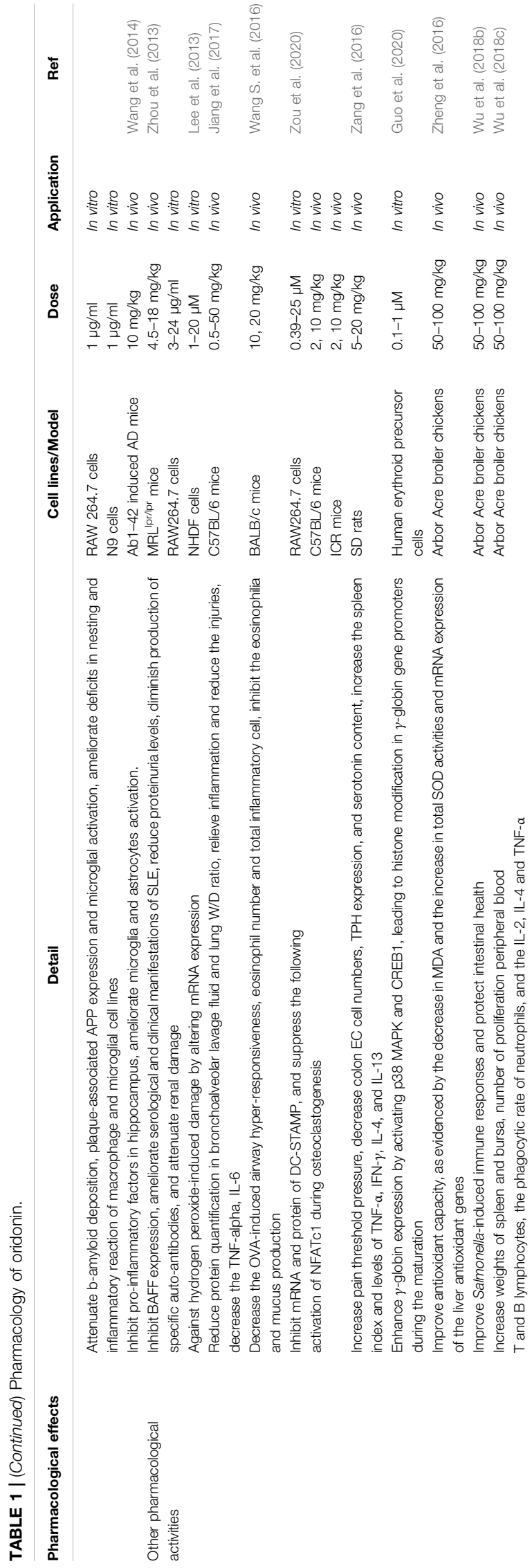

screening of candidate agents, which provides a novel approach to study modern pharmacotherapy (Sun et al., 2020a). Up to now, benefited from the continuous emergence of novel analytical techniques, researchers have investigated the pharmacokinetic parameters of oridonin in vivo by means of MS-MS (Jin et al., 2010), LC-MS-MS (Du et al., 2010; Jin et al., 2015) and other analytical methods with rats (Jian et al., 2007) and rabbits (Mei et al., 2008), which partially interpreted the kinds of events related to the efficacy and toxicity of relevant herbal preparations in which this constituent is used. Following rat oral administration of Herba Isodi Rubescentis extract containing oridonin $(1.68 \mathrm{mg} / \mathrm{kg})$, the pharmacokinetic parameters in rat plasma were obtained with the method of LC-MS-MS, revealing AUC0-t at $78.45 \pm 33.83 \mathrm{ng} / \mathrm{ml} / \mathrm{h}$ and $\mathrm{AUC}_{(0 \text {-infinity }}$ at $79.29 \pm 34.26 \mathrm{ng} / \mathrm{ml} / \mathrm{h}, \mathrm{t}_{1 / 2}$ at $0.19 \pm 0.05 \mathrm{~h}$, $\mathrm{T}_{\max }$ at $0.69 \pm 0.13 \mathrm{~h}, \mathrm{C}_{\max }$ at $164.51 \pm 58.42 \mathrm{ng} / \mathrm{ml}$ (Ma et al., 2013). Determination of oridonin $(40 \mathrm{mg} / \mathrm{kg})$ in rat plasma after intragastrical administration with determination of LC-MS-MS suggested that it mainly metabolized in liver, and acquired main pharmacokinetic parameters, such as $\mathrm{t}_{1 / 2}$ at $10.88 \pm 4.38 \mathrm{~h}$, $\mathrm{T}_{\max }$ at $1.00 \pm 0.12 \mathrm{~h}, \mathrm{C}_{\max }$ at $146.9 \pm 10.17 \mathrm{ng} / \mathrm{ml}, \mathrm{AUC}(0-\mathrm{t})$ at $1.31 \pm 0.29 \mathrm{mg} \mathrm{h} / \mathrm{L}$. At the same time, this project also told us that verapamil could substantially alter the pharmacokinetic profile of oridonin in rats, as well as it might exert these effects via elevating the absorption of this terpenoid compound by suppressing the activity of P-gp, or through hindering the metabolism of it in rat liver (Liu et al., 2019). Figure 3 shows the main metabolites of oridonin.

A strategy of using ultra-high-performance liquid chromatography-Triple/time-of-flight mass spectrometry (UPLC-Triple-TOF-MS/MS) to identify metabolites and evaluate the in vitro metabolic profile of oridonin corroborate that, oridonin is universally metabolized in vitro, which the metabolic pathway mainly consists of dehydration, hydroxylation, di-hydroxylation, hydrogenation, decarboxylation, and ketone formation. Meanwhile, 16 metabolites of I- and IIphase were identified (Ma Y. et al., 2016). Another similar study also indicated that 16 phase I and 2 phase II metabolites were detected after oral administration of oridonin in rats, and the main biotransformation pathways of oridonin were reduction, oxidation, dehydroxylation and glucuronic acid coupling (Tian et al., 2015). In addition, the treatment of HepaRG cells with oridonin at concentration of $1,5,10$, and $20 \mu \mathrm{M}$ demonstrated that oridonin induced the mRNA and protein expression and enzyme activity of CYP450s, especially on the CYP3A4 and CYP2C9 (Zhang Y. W. et al., 2018). Besides, studies have also shown that oridonin could induce the expression of human CYP3A4 mRNA and protein through pregnane X receptormediated (PXR) pathway. Notably, there is no effect on the expression of PXR-nnRNA and protein (Zhang Y.-w. et al., 2014). In the aspect of interaction between oridonin and blood protein, it could bind to human serum albumin (HAS) through hydrogen bonding and van der Waals force, and induce conformational changes of HSA, thus affecting its biological function as carrier protein. The research provides an accurate and full basic data for clarifying the binding mechanism of oridonin with HSA and is beneficial for comprehending its 


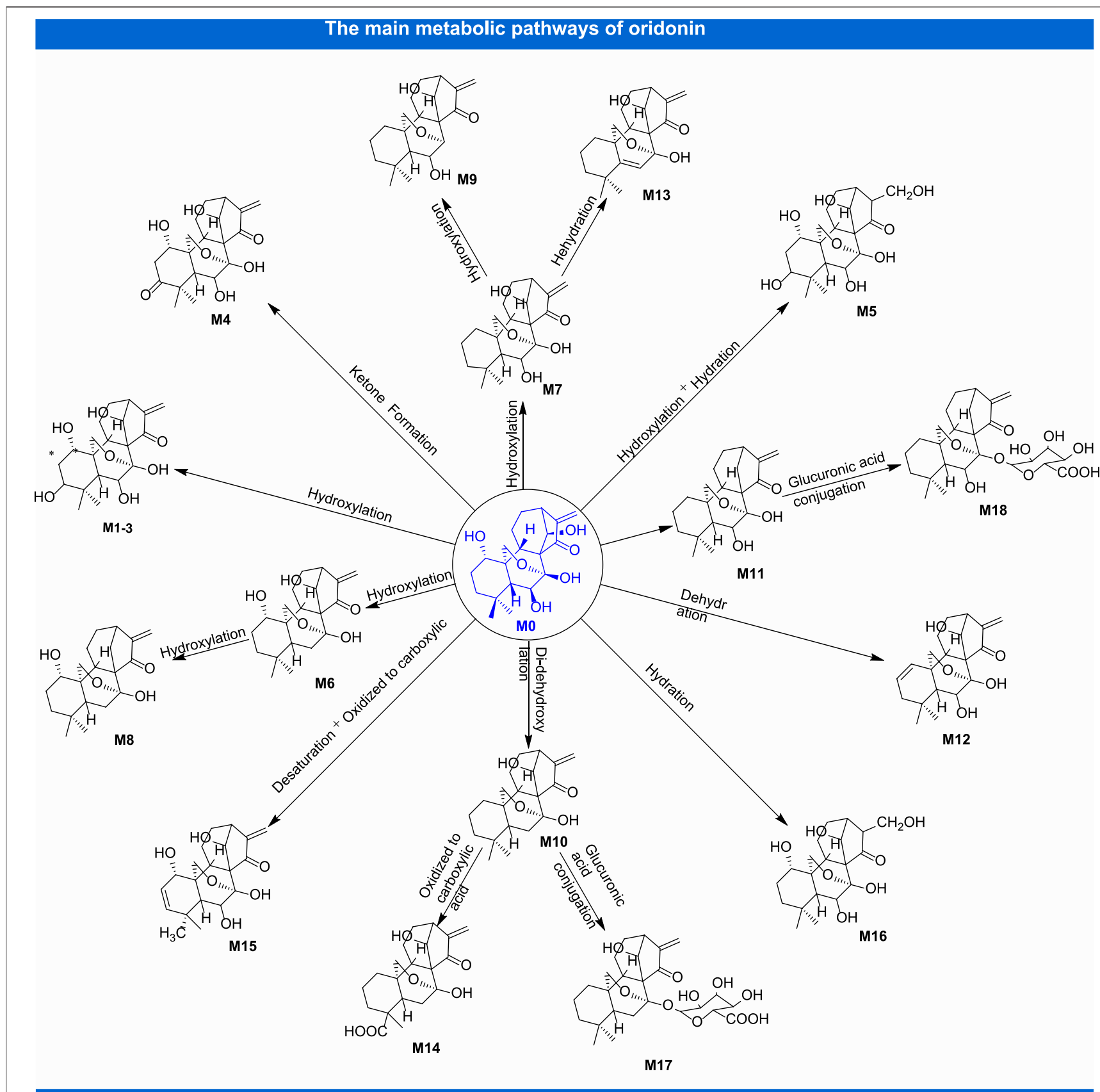

FIGURE 3 | The main metabolic pathways of oridonin.

activity on protein function and biological activity in vivo during blood transportation process (Li et al., 2015). Other pharmacokinetic studies on oridonin are shown in Table 2.

\section{TOXICITY}

When evaluating the efficacy of ingredients, the toxicity and safety of them should be considered particularly (Sun et al., 2020b). For a long time, traditional Chinese medicine (TCM) is well known for its safety. But in recent years, the adverse reactions have been reported frequently. Being a diterpenoids compound broadly distributed in medicinal plants, oridonin has an extensive range of pharmacological activities. However, several lines of evidence indicated that oridonin may exhibit adverse effects, even toxicity under specific circumstances, which sparked intense debate and concern about security of oridonin. As discussed above, it was discovered that oridonin showed antitumor activity on small cell 
TABLE 2 | Pharmacokinetic information of oridonin.

\begin{tabular}{|c|c|c|c|c|c|}
\hline Model & Dose & $\begin{array}{l}\text { Administration } \\
\text { method }\end{array}$ & Quantitative method & Detail & Ref \\
\hline Wistar rats & $12.5 \mathrm{mg} / \mathrm{kg}$ & $\begin{array}{l}\text { Intravenous } \\
\text { administration }\end{array}$ & RP-HPLC method & $\begin{array}{l}\mathrm{t}_{1 / 2 \alpha}=0.12 \mathrm{~h} \\
\mathrm{t}_{1 / 2 \beta}=6.06 \mathrm{~h} \\
\mathrm{CL}=1.56 \mathrm{~L} / \mathrm{kg} / \mathrm{h} \\
\mathrm{AUC}=7.96 \mu \mathrm{m} \mathrm{h} / \mathrm{ml} \\
\mathrm{V}_{\mathrm{d}}=1.83 \mathrm{~L} / \mathrm{kg}\end{array}$ & $\begin{array}{l}\text { Jian et al. } \\
(2007)\end{array}$ \\
\hline Rabbits & 2 mg/kg & $\begin{array}{l}\text { Injection } \\
\text { administration }\end{array}$ & HPLC method & $\begin{array}{l}\mathrm{t}_{1 / 2 \alpha}=0.11 \pm 0.05 \mathrm{~h} \\
\mathrm{t}_{1 / 2 \beta}=2.12 \pm 0.87 \mathrm{~h} \\
\mathrm{CL}=1.44 \pm 0.61 \mathrm{~h} \mathrm{~L} / \mathrm{kg} / \mathrm{h} \\
\mathrm{AUC}_{0-\infty}=3.53 \pm 1.31 \mu \mathrm{g} \mathrm{h} / \mathrm{ml} \\
\mathrm{V}_{\mathrm{d}}=1.72 \pm 0.16 \mathrm{~h} \\
\mathrm{MRT}=2.41 \pm 1.07 \mathrm{~h}\end{array}$ & $\begin{array}{l}\text { Mei et al. } \\
(2008)\end{array}$ \\
\hline SD rats & $1.68 \mathrm{mg} / \mathrm{kg}$ & $\begin{array}{l}\text { Intravenous } \\
\text { administration }\end{array}$ & LC-MS-MS method & $\begin{array}{l}\mathrm{t}_{1 / 2}=2.90 \pm 0.87 \mathrm{~h} \\
\mathrm{CL}=1.08 \pm 0.31 \mathrm{~h} \mathrm{~L} / \mathrm{kg} / \mathrm{h} \\
\mathrm{AUC}_{0-\infty}=980.74 \pm 287.15 \mathrm{ng} / \mathrm{ml} / \mathrm{h} \\
\mathrm{V}_{\mathrm{d}}=4.29 \pm 0.54 \mathrm{~h} \\
\mathrm{MRT}=1.79 \pm 0.77 \mathrm{~h}\end{array}$ & $\begin{array}{l}\text { Ma et al. } \\
(2013)\end{array}$ \\
\hline SD rats & 40 mg/kg & $\begin{array}{l}\text { Intragastrical } \\
\text { administration }\end{array}$ & LC-MS/MS method & $\begin{array}{l}\mathrm{t}_{1 / 2}=10.88 \pm 4.38 \mathrm{~h} \\
\mathrm{CL}=14.69 \pm 4.42 \mathrm{~h} \mathrm{~L} / \mathrm{kg} / \mathrm{h} \\
\mathrm{AUC}_{0-\infty}=1.31 \pm 0.29 \mathrm{mg} \mathrm{h} / \mathrm{L} \\
\mathrm{T}_{\max }=1.00 \pm 0.12 \mathrm{~h} \\
\mathrm{MRT}=9.25 \pm 1.10 \mathrm{~h}\end{array}$ & $\begin{array}{l}\text { Liu et al. } \\
(2019)\end{array}$ \\
\hline $\begin{array}{l}\text { Human liver } \\
\text { microsomes }\end{array}$ & $100 \mu \mathrm{M}$ & Mixed system & $\begin{array}{l}\text { UPLC-Triple-TOF-MS/MS } \\
\text { and PCA method }\end{array}$ & $\begin{array}{l}\text { The main metabolic pathways of oridonin include dehydration, } \\
\text { hydroxylation, dihydroxylation, hydrogenation, decarboxylation }\end{array}$ & $\begin{array}{l}\text { Ma S. et al. } \\
(2016)\end{array}$ \\
\hline $\begin{array}{l}\text { Monkey liver } \\
\text { microsomes }\end{array}$ & $100 \mu \mathrm{M}$ & & & and ketogenesis & \\
\hline $\begin{array}{l}\text { Rat liver } \\
\text { microsomes }\end{array}$ & $100 \mu \mathrm{M}$ & & & & \\
\hline $\begin{array}{l}\text { Mouse liver } \\
\text { microsomes }\end{array}$ & $100 \mu \mathrm{M}$ & & & & \\
\hline SD rats & $10 \mathrm{mg} / \mathrm{kg}$ & $\begin{array}{l}\text { Intragastric } \\
\text { administration }\end{array}$ & $\begin{array}{l}\text { UPLC-Triple-TOF-MS/MS } \\
\text { method }\end{array}$ & $\begin{array}{l}\text { The biotransformation of oridonin mainly includes reduction, } \\
\text { oxidation, dehydrogenation and glucuronic acid binding }\end{array}$ & $\begin{array}{l}\text { Tian et al. } \\
\text { (2007) }\end{array}$ \\
\hline HepaRG cells & $1-20 \mu \mathrm{M}$ & Mixed system & HPLC-MS/MS method & $\begin{array}{l}\text { Induce effects on the major member of CYP450s mRNA and } \\
\text { protein expression, as well as on the enzyme activity, especially } \\
\text { on CYP3A4 and CYP2C9 }\end{array}$ & $\begin{array}{l}\text { Zhang et al. } \\
\text { (2018b) }\end{array}$ \\
\hline $\begin{array}{l}\text { HepG2 cells } \\
\text { LS174T cells }\end{array}$ & $\begin{array}{l}20 \mu \mathrm{M} \\
20 \mu \mathrm{M}\end{array}$ & Mixed system & UPLC-MS/MS method & $\begin{array}{l}\text { Induce the CYP3A4 reporter luciferase activity, and up-regulate } \\
\text { CYP3A4 mRNA and protein levels, up-regulate enzymatic } \\
\text { activities of CYP3A4 }\end{array}$ & $\begin{array}{l}\text { Zhang et al. } \\
\text { (2014b) }\end{array}$ \\
\hline
\end{tabular}

lung cancer (SCLC), but at the same time, HE staining revealed a certain degree of cytotoxicity in hepatic tissue after treatment with oridonin $(10 \mathrm{mg} / \mathrm{kg}$ ) (Xu et al., 2020). In addition, intervention of oridonin induced abnormalities in zebrafish, such as uninflated swim bladder and pericardial congestion at an $\mathrm{EC}_{50}$ of $411.94 \mathrm{mg} / \mathrm{L}$ in vitro, as well as it also decreased the body length of zebrafish. In this article, researcher relied on the fact that the downregulation of VEGFR3 gene expression probably be related to the occurrence of abnormalities following oridonin exposure during embryonic development (Tian et al., 2019). A $48 \mathrm{~h}$ exposure to oridonin $(\geqslant 25 \mu \mathrm{M})$ sharply augmented cytosolic $\mathrm{Ca}^{+}$concentration, potentiated formation of ceramide, and then triggered suicidal death of erythrocytes (Jilani et al., 2011).

On the other hand, some reports suggested that oridonin could induce the expression and activation of CYP2C and CYP3A family (Zhang Y. W. et al., 2018), and appeared to be a potential risk to herb-drug interactions as a result of its induction effects on drug processing genes expression and activation (Zhang Y.-w. et al., 2014). Therefore, these reports suggested that we should pay attention to the safety issues caused by the combination of oridonin in clinical practice. Generally speaking, there are few adverse reports on the safety of oridonin, but the lack of reports does not mean that there are no such potential risks. In view of this, it is particularly important to explore the mechanisms responsible for the adverse risk of oridonin under particular circumstances. Other toxicity researches of oridonin are shown in Table 3.

\section{SUMMARY AND OUTLOOKS}

Oridonin exists in considerable number of traditional herbal medicines and possesses salient medicinal value. Numerous researches have exhibited that it can regulate a variety of gene and protein expression such as ALP, IL-6, TNF- $\alpha$, Bcl-2, caspase3 , PGE2, etc. It also shows extensive effects in the regulation of $\mathrm{NF}-\kappa \mathrm{B}, \mathrm{PI} 3 \mathrm{~K} / \mathrm{Akt} / \mathrm{mTOR}$, and ERK1/2 signaling pathways. This 
TABLE 3 | Toxicity researches of oridonin.

\begin{tabular}{|c|c|c|c|}
\hline Model & Dose & Detail & Ref \\
\hline BALB/c mice & $5-10 \mathrm{mg} / \mathrm{kg}$ & HE staining revealed a certain degree of cytotoxicity in hepatic tissue & Xu et al. (2020) \\
\hline Zebrafish & $100-400 \mathrm{mg} / \mathrm{L}$ & $\begin{array}{l}\text { Decrease heartbeat with IC50 of } 285.76 \mathrm{mg} / \mathrm{L} \text { at } 48 \mathrm{~h} \text {, induce malformation at } 120 \mathrm{~h} \text { with half maximal } \\
\text { effective concentration of } 411.94 \mathrm{mg} / \mathrm{L}\end{array}$ & Tian et al. (2019) \\
\hline Erythrocytes & $1 \mathrm{mM}$ & Trigger $\mathrm{Ca}^{2+}$ entry and ceramide formation as well as suicidal death of erythrocytes & Jilani et al. (2011) \\
\hline $\begin{array}{l}\text { PXR-humanized } \\
\text { mice }\end{array}$ & $25-200 \mathrm{mg} / \mathrm{kg}$ & $\begin{array}{l}\text { Induce the expression and activation of CYP2c and CYP3a family, which might contribute to potential } \\
\text { drug-drug interactions and appear to be a risk when co-administered with other clinical drugs }\end{array}$ & $\begin{array}{l}\text { Zhang et al. } \\
(2018 b)\end{array}$ \\
\hline C57BL/6 mice & $25-200 \mathrm{mg} / \mathrm{kg}$ & $\begin{array}{l}\text { Appear to be a potential risk to herb-drug interactions as a result of its induction effects on drug processing } \\
\text { genes expression and activation }\end{array}$ & $\begin{array}{l}\text { Zhang et al. } \\
\text { (2014b) }\end{array}$ \\
\hline
\end{tabular}

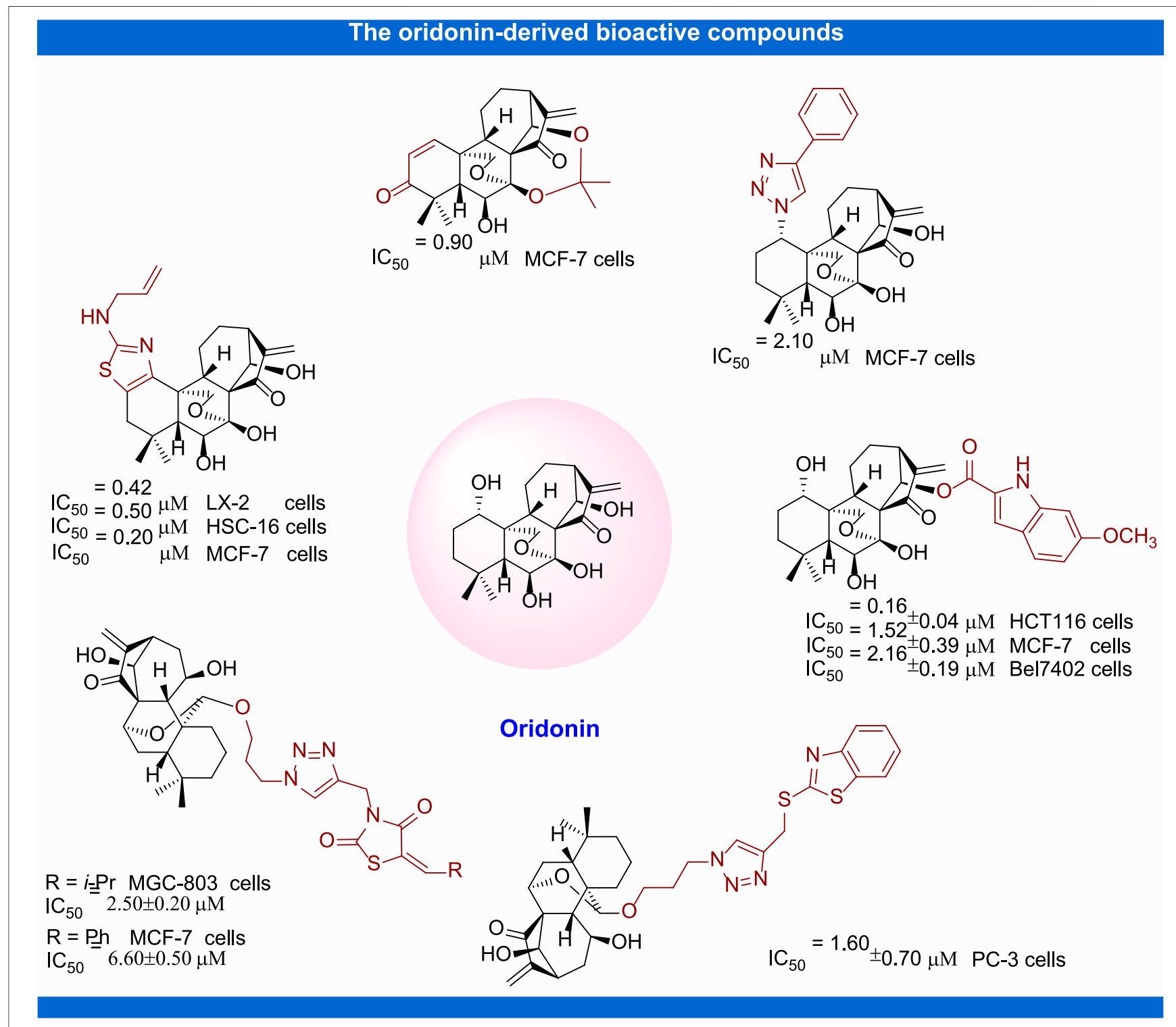

FIGURE 4 | The structural modification of oridonin.

review summarized the mechanism by which oridonin is utilized to treat related diseases (as shown in Table 1) and the related parameters of the pharmacokinetics (as shown in Table 2), as well as security problems in clinical practice (as shown in Table 3). However, there are some issues that need further clarification in future research. 
Although oridonin has been proved to possess assorted pharmacological activities in vivo and in vitro, the specific mechanism of its biological activity has not been fully expounded. Hence, it is severely significant to further excavate the mechanism of pharmacological activity at molecular level.

Additionally, as described herein, it has shown prominent adverse effects, even toxicity under specific circumstances in vitro and in vivo. Hence, the conduction of essential investigations and comprehensive strategies to strike the balance between toxicological safety and therapeutic efficacy, as well as the establishment of an all-round research on the effect of dosage on pharmacological activity and toxicity, is highly demanded in this field.

As described herein, oridonin has shown prominent adverse effects, even toxicity under specific circumstances in vitro and in vivo. It showed hepatotoxicity and hepatoprotective effects, which the pair of pharmacological activities seems to be a paradox. However, through the analysis, it is found that this is mainly related to the concentration of oridonin and the time of administration. Long-term administration and high dose administration may cause liver damage. Therefore, it is necessary to further investigate the effects of the concentration of oridonin on pharmacological effects and toxicity. On the other hand, according to the chemical structure of oridonin, it may react covalently with the sulfhydryl group of some proteins, which can partly explain the reason of adverse reactions even toxicity of oridonin in specific environment. In addition, based on the analysis of the existing literatures, we think that the current researches are focus more on the toxicity of oridonin itself. Nevertheless, the toxic process of oridonin metabolites is still unknown. These aspects can be further interpreted in future. Therefore, in view of the above reasons for the safety of oridonin, we suggest that the conduction of essential investigations and comprehensive strategies to strike the balance between toxicological safety and therapeutic efficacy are necessary, as well as the establishment of an all-round research on the effect of dosage on pharmacological activity and toxicity, is highly demanded in this field.

In recent years, structural modification of oridonin, including 1) the derivatization of hydroxyl groups, 2) modification of A-ring, 3) modification of the enone system, and 4) the transformation and derivatization of the framework structure, has been conducted in order to ameliorate the activity and amplify their application scope (Zhang et al., 2020). In the past decades, great progress has been made in structure activity relationship and mechanism of action studies of oridonin for the treatment of malignant tumor and other diseases

\section{REFERENCES}

Bae, S., Lee, E.-J., Lee, J. H., Park, I.-C., Lee, S.-J., Hahn, H. J., et al. (2014). Oridonin Protects Hacat Keratinocytes against Hydrogen Peroxide-Induced Oxidative Stress by Altering Microrna Expression. Int. J. Mol. Med. 33, 185-193. doi:10.3892/ijmm.2013.1561

Bi, E., Liu, D., Li, Y., Mao, X., Wang, A., and Wang, J. (2018). Oridonin Induces Growth Inhibition and Apoptosis in Human Gastric Carcinoma Cells by Enhancement of P53 Expression and Function. Braz. J. Med. Biol. Res. 51, e7599. doi:10.1590/1414-431X20187599
(Figure 4). The structure and activity relation studies based on these new derivatives have tremendously contributed to the comprehension of their mechanism of actions and molecular targets.

According to the above literatures, we deeply realized that an increasing number of reports indicate that oridonin has miscellaneous positive pharmacological activities. However, on the whole, the oridonin's specific mechanism related various diseases still remain to be clarified. On the other hand, although this natural active ingredient can positively influence the disease process by regulating multiple signal pathways or targets, it is only utilized as adjuvant agents in clinical practice, and rarely applied in the treatment of specific diseases. Therefore, in consideration of the current scattered research, detailed mechanism of oridonin in the treatment of specific diseases should be systematically integrated in the future.

\section{AUTHOR CONTRIBUTIONS}

$\mathrm{XL}$ and $\mathrm{QH}$ contributed to the conception and design of the study. XL, WM, and C-TZ organized the database, performed the statistical analysis, and wrote the first draft of the manuscript. XX and QH contributed to the manuscript revision. All authors read and approved the submitted version.

\section{FUNDING}

Financial support was provided by the China Postdoctoral Science Foundation, Grant/Award Number: 2020M673295, 2020T130273; Project of the Open Research Fund of Chengdu University of Traditional Chinese Medicine Key Laboratory of Systematic Research of Distinctive Chinese Medicine Resources in Southwest China, Grant/Award Number: 2020BSH008; Xinglin Scholar Research Promotion Project of Chengdu University of TCM, Grant/Award Number: YXRC2019004, ZRYY1922, BSH2020018; Sichuan Science and technology program, Grant/Award Number: 2020JDRC0114, 2020YFH0164; Special Project of Science and Technology Research of Sichuan Administration of Traditional Chinese Medicine, Grant/Award Number: 2021MS093, 2021MS539; "100 Talent Plan" Project of Hospital of Chengdu University of Traditional Chinese Medicine, Grant/Award Number: Hospital office (2020) 42; Science and technology development fund of Hospital of Chengdu University of traditional Chinese Medicine, Grant/Award Number: 19SX01, 19YY10, 20YY12, 19LW19.

Bohanon, F. J., Wang, X., Ding, C., Ding, Y., Radhakrishnan, G. L., Rastellini, C., et al. (2014). Oridonin Inhibits Hepatic Stellate Cell Proliferation and Fibrogenesis. J. Surg. Res. 190, 55-63. doi:10.1016/j.jss.2014.03.036

Bu H.-Q., H.-Q., Shen, F., and Cui, J. (2019). The Inhibitory Effect of Oridonin on colon Cancer Was Mediated by Deactivation of TGF- $\beta 1 /$ Smads-PAI- 1 Signaling Pathway In Vitro and Vivo. Onco Targets Ther. 12, 7467-7476. doi:10.2147/Ott.S220401

Bu H., H., Liu, D., Cui, J., Cai, K., and Shen, F. (2019). Wnt/ $\beta$-catenin Signaling Pathway Is Involved in Induction of Apoptosis by Oridonin in colon Cancer COLO205 Cells. Transl. Cancer Res. 8, 1782-1794. doi: $10.21037 /$ tcr.2019.08.25 
Cao, S., Huang, Y., Zhang, Q., Lu, F., Donkor, P. O., Zhu, Y., et al. (2019). Molecular Mechanisms of Apoptosis and Autophagy Elicited by Combined Treatment with Oridonin and Cetuximab in Laryngeal Squamous Cell Carcinoma. Apoptosis 24, 33-45. doi:10.1007/s10495-018-1497-0

Chen, K., Ye, J., Qi, L., Liao, Y., Li, R., Song, S., et al. (2019). Oridonin Inhibits Hypoxia-Induced Epithelial-Mesenchymal Transition and Cell Migration by the Hypoxia-Inducible Factor-1 $\alpha$ /matrix Metallopeptidase-9 Signal Pathway in Gallbladder Cancer. Anti-Cancer Drug 30, 925-932. doi:10.1097/ Cad.0000000000000797

Cheng, W., Huang, C., Ma, W., Tian, X., and Zhang, X. (2018). Recent Development of Oridonin Derivatives with Diverse Pharmacological Activities. Mini Rev Med Chem. 19, 114-124. doi:10.2174/ 1389557517666170417170609

Clayton, J. E., Held, P. G., Larson, B., and Banks, P. (2016). Quantification of Oridonin-Induced Apoptosis and Cytotoxicity in Cancer Cells Using Noninvasive Live-Cell Imaging. Mol. Biol. Cel 27, P1088.

Cummins, C. B., Wang, X., Sommerhalder, C., Bohanon, F. J., Nunez Lopez, O., Tie, H.-Y., et al. (2018). Natural Compound Oridonin Inhibits EndotoxinInduced Inflammatory Response of Activated Hepatic Stellate Cells. Biomed. Res. Int. 2018, 1-10. doi:10.1155/2018/6137420

Cummins, C., Wang, X., Gu, Y., Fang, X., and Radhakrishnan, R. (2019). Protective Effects of Oridonin on Intestinal Epithelial Cells by Suppressing TNFa-Induced Inflammation and Epithelial-Mesenchymal Transition. J. Am. Coll. Surgeons 229, e239-e240. doi:10.1016/j.jamcollsurg.2019.08.1390

Deng, Y., Chen, C., Yu, H., Diao, H., Shi, C., Wang, Y., et al. (2017). Oridonin Ameliorates Lipopolysaccharide/d-Galactosamine-Induced Acute Liver Injury in Mice via Inhibition of Apoptosis. Am. J. Transl Res. 9, 4271-4279.

Dong, X., Liu, F., and Li, M. (2016). Inhibition of Nuclear Factor $\kappa B$ Transcription Activity Drives a Synergistic Effect of Cisplatin and Oridonin on HepG2 Human Hepatocellular Carcinoma Cells. Anti-Cancer Drug 27, 286-299. doi:10.1097/Cad.0000000000000329

Dong, Y. L., Huang, C. P., and Li, J. (2018). The Inhibitive Effects of Oridonin on CisplatinResistant Ovarian Cancer Cells via Inducing Cell Apoptosis and Inhibiting Adam17. Acta Med. Mediterr 34, 819-825. doi:10.19193/0393-6384_2018_3_125

Du, Y., Liu, P., Shi, X., Jin, Y., Wang, Q., Zhang, X., et al. (2010). A Novel Analysis Method for Diterpenoids in Rat Plasma by Liquid ChromatographyElectrospray Ionization Mass Spectrometry. Anal. Biochem. 407, 111-119. doi:10.1016/j.ab.2010.07.009

Fu, Y., Zhao, P., Xie, Z., Wang, L., and Chen, S. (2018). Oridonin Inhibits Myofibroblast Differentiation and Bleomycin-Induced Pulmonary Fibrosis by Regulating Transforming Growth Factor $\beta$ (TGF $\beta) / S m a d$ Pathway. Med. Sci. Monit. 24, 7548-7555. doi:10.12659/Msm.912740

Gao, S., Tan, H., Zhu, N., Gao, H., Lv, C., Gang, J., et al. (2016). Oridonin Induces Apoptosis through the Mitochondrial Pathway in Human Gastric Cancer Sgc7901 Cells. Int. J. Oncol. 48, 2453-2460. doi:10.3892/ijo.2016.3479

Gong, L., Xu, H., Zhang, X., Zhang, T., Shi, J., and Chang, H. (2019). Oridonin Relieves Hypoxia-Evoked Apoptosis and Autophagy via Modulating Microrna214 in H9c2 Cells. Artif. Cell Nanomedicine, Biotechnol. 47, 2585-2592. doi:10.1080/21691401.2019.1628037

Gu, Z., Wang, X., Qi, R., Wei, L., Huo, Y., Ma, Y., et al. (2015). Oridonin Induces Apoptosis in Uveal Melanoma Cells by Upregulation of Bim and Downregulation of Fatty Acid Synthase. Biochem. Biophysical Res. Commun. 457, 187-193. doi:10.1016/j.bbrc.2014.12.086

Gui, Z., Li, S., Liu, X., Xu, B., and Xu, J. (2015). Oridonin Alters the Expression Profiles of Micrornas in Bxpc-3 Human Pancreatic Cancer Cells. BMC Complement. Altern. Med. 15, 117. doi:10.1186/s12906-015-0640-5

Gui, Z., Luo, F., Yang, Y., Shen, C., Li, S., and Xu, J. (2017). Oridonin Inhibition and Mir-200b-3p/zeb1 axis in Human Pancreatic Cancer. Int. J. Oncol. 50, 111-120. doi:10.3892/ijo.2016.3772

Guo, L., Chen, J., Wang, Q., Zhang, J., and Huang, W. (2020). Oridonin Enhances $\gamma$-globin Expression in Erythroid Precursors from Patients with $\beta$-thalassemia via Activation of P38 MAPK Signaling. Mol. Med. Rep. 21, 909-917. doi:10.3892/mmr.2019.10848

Guo, W., Zheng, P., Zhang, J., Ming, L., Zhou, C., and Zhang, S. (2013). Oridonin Suppresses Transplant Rejection by Depleting T Cells from the Periphery. Int. Immunopharmacology 17, 1148-1154. doi:10.1016/j.intimp.2013.10.023
Han, J. M., Hong, K. O., Yang, I. H., Ahn, C. H., Jin, B., Lee, W., et al. (2020). Oridonin Induces the Apoptosis of Mucoepidermoid Carcinoma Cell Lines in a Myeloid Cell Leukemia-1-dependent Manner. Int. J. Oncol. 57, 377-385. doi:10.3892/ijo.2020.5061

Hao, Y., Li, J., Luo, Y. Y., Zhang, M., and Li, S. S. (2016). Proteomic Research on Honeybee. J. Tradit Chin. Med. 36, 225-252. doi:10.1007/978-3-31943275-5_12

He, H. B., Jiang, H., Chen, Y., Deng, X., Jiang, W., and Zhou, R. (2019). Oridonin Is a Covalent Nlrp3 Inhibitor with strong Anti-inflammasome Activity. Eur. J. Immunol. 49, 192.

He, S.-D., Huang, S.-G., Zhu, H.-J., Luo, X.-G., Liao, K.-H., Zhang, J.-Y., et al. (2020). Oridonin Suppresses Autophagy and Survival in Rheumatoid Arthritis Fibroblast-like Synoviocytes. Pharm. Biol. 58, 146-151. doi:10.1080/ 13880209.2020.1711783

He, Z., Xiao, X., Li, S., Guo, Y., Huang, Q., Shi, X., et al. (2017). Oridonin Induces Apoptosis and Reverses Drug Resistance in Cisplatin Resistant Human Gastric Cancer Cells. Oncol. Lett. 14, 2499-2504. doi:10.3892/ol.2017.6421

Hu, X., Wang, Y., Gao, X., Xu, S., Zang, L., Xiao, Y., et al. (2020). Recent Progress of Oridonin and its Derivatives for the Treatment of Acute Myelogenous Leukemia. Mini Rev Med Chem 20, 483-497. doi:10.2174/ 1389557519666191029121809

Huang, J.-H., Lan, C.-C., Hsu, Y.-T., Tsai, C.-L., Tzeng, I.-S., Wang, P., et al. (2020). Oridonin Attenuates Lipopolysaccharide-Induced Ros Accumulation and Inflammation in Hk-2 Cells. Evidence-Based Complement. Altern. Med. 2020, 1-8. doi:10.1155/2020/9724520

Huang, W., Huang, M., Ouyang, H., Peng, J., and Liang, J. (2018). Oridonin Inhibits Vascular Inflammation by Blocking NF- $\kappa$ B and MAPK Activation. Eur. J. Pharmacol. 826, 133-139. doi:10.1016/j.ejphar.2018.02.044

Jeon, M.-Y., Seo, S. U., Woo, S. M., Min, K.-j., Byun, H. S., Hur, G. M., et al. (2019). Oridonin Enhances Trail-Induced Apoptosis through Galnt14-Mediated Dr5 Glycosylation. Biochimie 165, 108-114. doi:10.1016/j.biochi.2019.07.015

Jia, T., Cai, M., Ma, X., Li, M., Qiao, J., and Chen, T. (2019). Oridonin Inhibits IL$1 \beta$-induced Inflammation in Human Osteoarthritis Chondrocytes by Activating PPAR- $\gamma$. Int. Immunopharmacology 69, 382-388. doi:10.1016/ j.intimp.2019.01.049

Jian, G., Wang, Y.-W., Lu, X.-C., and Cao, J.-Y. (2007). Determination of Oridonin in Rat Plasma by Reverse-phase High-Performance Liquid Chromatography. J. Pharm. Biomed. Anal. 43, 793-797. doi:10.1016/j.prp.2020.153031

Jian, Z. Y., Xu, G. F., and Dai, L. (2019). Analysis on the Accumulation of Oridonin in Different Portions of Isodon Rubescens (Hemsley) H. Hara. Bangladesh J. Bot. 48, 1193-1197. doi:10.3329/bjb.v48i4.49075

Jiang, J.-H., Pi, J., and Cai, J.-Y. (2020). Oridonin Exhibits Anti-angiogenic Activity in Human Umbilical Vein Endothelial Cells by Inhibiting Vegf-Induced Vegfr2 Signaling Pathway. Pathol. - Res. Pract. 216, 153031. doi:10.1016/ j.prp.2020.153031

Jiang, J. H., Pi, J., Jin, H., and Cai, J. Y. (2019). Oridonin-induced Mitochondriadependent Apoptosis in Esophageal Cancer Cells by Inhibiting PI3K/AKT/ mTOR and Ras/Raf Pathways. J. Cel Biochem 120, 3736-3746. doi:10.1002/ jcb. 27654

Jiang, J., Shan, X. X., and Zhu, L. (2017). Effects and Mechanisms of Oridonin in the Treatment of Acute Respiratory Distress Syndrome Mice. Int. J. Clin. Exp. Med. 10, 6191-6197.

Jilani, K., Qadri, S. M., Zelenak, C., and Lang, F. (2011). Stimulation of Suicidal Erythrocyte Death by Oridonin. Arch. Biochem. Biophys. 511, 14-20. doi:10.1016/j.abb.2011.05.001

Jin, Y., Du, Y., Shi, X., and Liu, P. (2010). Simultaneous Quantification of 19 Diterpenoids in Isodon Amethystoides by High-Performance Liquid Chromatography-Electrospray Ionization Tandem Mass Spectrometry. J. Pharm. Biomed. Anal. 53, 403-411. doi:10.1016/j.jpba.2010.04.030

Jin, Y., Tian, T., Ma, Y., Xu, H., and Du, Y. (2015). Simultaneous Determination of Ginsenoside Rb1, Naringin, Ginsenoside Rb2 and Oridonin in Rat Plasma by LC-MS/MS and its Application to a Pharmacokinetic Study after Oral Administration of Weifuchun Tablet. J. Chromatogr. B 1000, 112-119. doi:10.1016/j.jchromb.2015.06.027

Kadioglu, O., Saeed, M., Kuete, V., Greten, H. J., and Efferth, T. (2018). Oridonin Targets Multiple Drug-Resistant Tumor Cells as Determined by In Silico and In Vitro Analyses. Front. Pharmacol. 9, 355. doi:10.3389/fphar.2018.00355 
Kang, N., Cao, S.-J., Zhou, Y., He, H., Tashiro, S.-I., Onodera, S., et al. (2015). Inhibition of Caspase- 9 by Oridonin, a Diterpenoid Isolated from Rabdosia Rubescens, Augments Apoptosis in Human Laryngeal Cancer Cells. Int. J. Oncol. 47, 2045-2056. doi:10.3892/ijo.2015.3186

Kang, N., Cao, S., Jiang, B., Zhang, Q., Donkor, P. O., Zhu, Y., et al. (2020). Cetuximab Enhances Oridonin-Induced Apoptosis through Mitochondrial Pathway and Endoplasmic Reticulum Stress in Laryngeal Squamous Cell Carcinoma Cells. Toxicol. Vitro 67, 104885. doi:10.1016/ j.tiv.2020.104885

Lee, E.-J., Cha, H. J., Ahn, K. J., An, I.-S., An, S., and Bae, S. (2013). Oridonin Exerts Protective Effects against Hydrogen Peroxide-Induced Damage by Altering Microrna Expression Profiles in Human Dermal Fibroblasts. Int. J. Mol. Med. 32, 1345-1354. doi:10.3892/ijmm.2013.1533

Li, C., Wang, Q., Shen, S., Wei, X., and Li, G. (2018). Oridonin Inhibits VEGF-Aassociated Angiogenesis and Epithelial-mesenchymal Transition of Breast Cancer In Vitro and In Vivo. Oncol. Lett. 16, 2289-2298. doi:10.3892/ ol.2018.8943

Li, C. Y., Wang, Q., Shen, S., Wei, X. L., and Li, G. X. (2018). Oridonin Inhibits Migration, Invasion, Adhesion and TGF- $\beta 1$-induced Epithelial-mesenchymal Transition of Melanoma Cells by Inhibiting the Activity of PI3K/Akt/GSK-3 $\beta$ Signaling Pathway. Oncol. Lett. 15, 1362-1372. doi:10.3892/ol.2017.7421

Li, D., Han, T., Xu, S., Zhou, T., Tian, K., Hu, X., et al. (2016). Antitumor and Antibacterial Derivatives of Oridonin: A Main Composition of Dong-Ling-Cao. Molecules 21, 575. doi:10.3390/molecules21050575

Li, J., Bao, L., Zha, D., Zhang, L., Gao, P., Zhang, J., et al. (2018). Oridonin Protects against the Inflammatory Response in Diabetic Nephropathy by Inhibiting the TLR4/p38-MAPK and TLR4/NF- $\mathrm{kB}$ Signaling Pathways. Int. Immunopharmacology 55, 9-19. doi:10.1016/j.intimp.2017.11.040

Li, J., Wu, Y., Wang, D., Zou, L., Fu, C., Zhang, J., et al. (2019). Oridonin Synergistically Enhances the Anti-tumor Efficacy of Doxorubicin against Aggressive Breast Cancer via Pro-apoptotic and Anti-angiogenic Effects. Pharmacol. Res. 146, 104313. doi:10.1016/j.phrs.2019.104313

Li, S., Shi, D., Zhang, L., Yang, F., and Cheng, G. (2018). Oridonin Enhances the Radiosensitivity of Lung Cancer Cells by Upregulating Bax and Downregulating Bcl-2. Exp. Ther. Med. 16, 4859-4864. doi:10.3892/etm.2018.6803

Li, W., and Ma, L. (2019). Synergistic Antitumor Activity of Oridonin and Valproic Acid on HL-60 Leukemia Cells. J. Cel Biochem 120, 5620-5627. doi:10.1002/ jcb. 27845

Li, X., and Yang, Z. (2015). Interaction of Oridonin with Human Serum Albumin by Isothermal Titration Calorimetry and Spectroscopic Techniques. ChemicoBiological Interactions 232, 77-84. doi:10.1016/j.cbi.2015.03.012

Li, Y.-C., Sun, M.-R., Zhao, Y.-H., Fu, X.-Z., Xu, H.-W., and Liu, J.-F. (2016). Oridonin Suppress Cell Migration via Regulation of Nonmuscle Myosin Iia. Cytotechnology 68, 389-397. doi:10.1007/s10616-014-9790-4

Li, Y., Wang, Y., Wang, S., Gao, Y., Zhang, X., Lu, C. H., et al. (2015). Oridonin Phosphate-Induced Autophagy Effectively Enhances Cell Apoptosis of Human Breast Cancer Cells. Med. Oncol. 32, 365. doi:10.1007/s12032014-0365-1

Liang, J., Wang, W., Wei, L., Gao, S., and Wang, Y. (2018). Oridonin Inhibits Growth and Induces Apoptosis of Human Neurocytoma Cells via the Wnt/ $\beta$-catenin Pathway. Oncol. Lett. 16, 3333-3340. doi:10.3892/ol.2018.8977

Liermann, J., Naumann, P., Fortunato, F., Schmid, T. E., Weber, K.-J., Debus, J., et al. (2017). Phytotherapeutics Oridonin and Ponicidin Show Additive Effects Combined with Irradiation in Pancreatic Cancer In Vitro. Radiol. Oncol. 51, 407-414. doi:10.1515/raon-2017-0048

Lin, K.-H., Li, C.-Y., Hsu, Y.-M., Tsai, C.-H., Tsai, F.-J., Tang, C.-H., et al. (2019). Oridonin, A Natural Diterpenoid, Protected NGF-Differentiated PC12 Cells against MPP+- and Kainic Acid-Induced Injury. Food Chem. Toxicol. 133, 110765. doi:10.1016/j.fct.2019.110765

Liu, D.-L., Bu, H.-Q., Jin, H.-M., Zhao, J.-F., Li, Y., and Huang, H. (2014). Enhancement of the Effects of Gemcitabine against Pancreatic Cancer by Oridonin via the Mitochondrial Caspase-dependent Signaling Pathway. Mol. Med. Rep. 10, 3027-3034. doi:10.3892/mmr.2014.2584

Liu, D.-L., Bu, H.-Q., Wang, W.-L., Luo, H., and Cheng, B.-N. (2020). Oridonin Enhances the Anti-tumor Activity of Gemcitabine towards Pancreatic Cancer by Stimulating Bax- and Smac-dependent Apoptosis. Transl Cancer Res. TCR 9, 4148-4161. doi:10.21037/tcr-19-3000
Liu, D., Qin, H., Yang, B., Du, B., and Yun, X. (2020). Oridonin Ameliorates Carbon Tetrachloride-induced Liver Fibrosis in Mice through Inhibition of the NLRP3 Inflammasome. Drug Dev. Res. 81, 526-533. doi:10.1002/ddr.21649

Liu, H., Gu, C., Liu, M., Liu, G., and Wang, Y. (2020). Nek7 Mediated Assembly and Activation of Nlrp3 Inflammasome Downstream of Potassium Efflux in Ventilator-Induced Lung Injury. Biochem. Pharmacol. 177, 113998. doi:10.1016/j.bcp.2020.113998

Liu, J., Zhang, N., Li, N., Fan, X., Li, Y., and Li, Y. (2019). Influence of Verapamil on the Pharmacokinetics of Oridonin in Rats. Pharm. Biol. 57, 787-791. doi:10.1080/13880209.2019.1688844

Liu, R.-X., Ma, Y., Hu, X.-L., Ren, W.-Y., Liao, Y.-P., Wang, H., et al. (2018). Anticancer Effects of Oridonin on colon Cancer Are Mediated via Bmp7/ p38 Mapk/p53 Signaling. Int. J. Oncol. 53, 2091-2101. doi:10.3892/ ijo.2018.4527

Liu, W., Huang, G., Yang, Y., Gao, R., Zhang, S., and Kou, B. (2021). Oridonin Inhibits Epithelial-Mesenchymal Transition of Human Nasopharyngeal Carcinoma Cells by Negatively Regulating Akt/stat3 Signaling Pathway. Int. J. Med. Sci. 18, 81-87. doi:10.7150/ijms.48552

Liu, X., Kang, J., Wang, H., Huang, T., and Huang, T. (2018). Mitochondrial Ros Contribute to Oridonin-Induced Hepg2 Apoptosis through Parp Activation. Oncol. Lett. 15, 2881-2888. doi:10.3892/ol.2017.7665

Liu, Y., Zhang, P.-x., Han, C.-h., Wei, D., Qiao, T., Peng, B., et al. (2017). Oridonin Protects the Lung against Hyperoxia-Induced Injury in a Mouse Model. Undersea Hyperb Med 44, 33-38. doi:10.22462/1.2.2017.6

Lou, S., Xu, J., Wang, B., Li, S., Ren, J., Hu, Z., et al. (2019). Downregulation of Lncrna Afap1-As1 by Oridonin Inhibits the Epithelial-To-Mesenchymal Transition and Proliferation of Pancreatic Cancer Cells. Acta Bioch Bioph Sin 51, 814-825. doi:10.1093/abbs/gmz071

Lu, C., Chen, C., Chen, A., Wu, Y., Wen, J., Huang, F., et al. (2020). Oridonin Attenuates Myocardial Ischemia/reperfusion Injury via Downregulating Oxidative Stress and Nlrp3 Inflammasome Pathway in Mice. Evidence-Based Complement. Altern. Med. 2020, 1-9. doi:10.1155/2020/7395187

Lu, J., Chen, X., Qu, S., Yao, B., Xu, Y., Wu, J., et al. (2017). Oridonin Induces G2/M Cell Cycle Arrest and Apoptosis via the PI3K/Akt Signaling Pathway in Hormone-independent Prostate Cancer Cells. Oncol. Lett. 13, 2838-2846. doi:10.3892/ol.2017.5751

Ma, B., Wang, Y., Zhang, Q., Liu, Y., Li, J., Xu, Q., et al. (2013). Simultaneous Determination of Oridonin, Ponicidin and Rosmarinic Acid from Herba Isodi Rubescentis Extract by Lc-Ms-Ms in Rat Plasma. J. Chromatogr. Sci. 51, 910-918. doi:10.1093/chromsci/bms189

Ma S., S., Tan, W., Du, B., Liu, W., Li, W., Che, D., et al. (2016). Oridonin Effectively Reverses Cisplatin Drug Resistance in Human Ovarian Cancer Cells via Induction of Cell Apoptosis and Inhibition of Matrix Metalloproteinase Expression. Mol. Med. Rep. 13, 3342-3348. doi:10.3892/mmr.2016.4897

Ma Y., Y., Xie, W., Tian, T., Jin, Y., Xu, H., Zhang, K., et al. (2016). Identification and Comparative Oridonin Metabolism in Different Species Liver Microsomes by Using Uplc-Triple-Tof-Ms/ms and Pca. Anal. Biochem. 511, 61-73. doi:10.1016/j.ab.2016.08.004

Mei, Y., Xu, J., Zhao, J., Feng, N., Liu, Y., and Wei, L. (2008). An Hplc Method for Determination of Oridonin in Rabbits Using Isopsoralen as an Internal Standard and its Application to Pharmacokinetic Studies for OridoninLoaded Nanoparticles. J. Chromatogr. B 869, 138-141. doi:10.1016/ j.jchromb.2008.05.005

Meng, L., Gui, X., and Yun, Z. (2019). A New Method to Extract Oridonin and Rosmarinic Acid Simultaneously from Rabdosia Rubescens. Int. J. Food Eng. 15, 1-11. doi:10.1515/ijfe-2019-0013

Oh, H.-N., Seo, J.-H., Lee, M.-H., Yoon, G., Cho, S.-S., Liu, K., et al. (2018). Oridonin Induces Apoptosis in Oral Squamous Cell Carcinoma Probably through the Generation of Reactive Oxygen Species and the P38/jnk Mapk Pathway. Int. J. Oncol. 52, 1749-1759. doi:10.3892/ijo.2018.4319

Park, H., Jeong, Y., Han, N.-K., Kim, J., and Lee, H.-J. (2018). Oridonin Enhances Radiation-Induced Cell Death by Promoting DNA Damage in Non-small Cell Lung Cancer Cells. Int J Mol Sci. 19, 2378. doi:10.3390/ijms19082378

Pi, J., Cai, H., Jin, H., Yang, F., Jiang, J., Wu, A., et al. (2015). Qualitative and Quantitative Analysis of Ros-Mediated Oridonin-Induced Oesophageal Cancer Kyse-150 Cell Apoptosis by Atomic Force Microscopy. Plos One 10, e0140935. doi:10.1371/journal.pone.0140935 
Qing, K., Jin, Z., Fu, W., Wang, W., Liu, Z., Li, X., et al. (2016). Synergistic Effect of Oridonin and a Pi3k/mtor Inhibitor on the Non-germinal center B Cell-like Subtype of Diffuse Large B Cell Lymphoma. J. Hematol. Oncol. 9, 72. doi:10.1186/s13045-016-0303-0

Ren, C.-M., Li, Y., Chen, Q.-Z., Zeng, Y.-H., Shao, Y., Wu, Q.-X., et al. (2016). Oridonin Inhibits the Proliferation of Human colon Cancer Cells by Upregulating Bmp7 to Activate P38 Mapk. Oncol. Rep. 35, 2691-2698. doi:10.3892/or.2016.4654

Ren, D. L., Ghoorun, R., Wu, X. H., Chen, H. L., Zhou, Q., and Wu, X. B. (2020). Oridonin Induces Apoptosis in HGC-27 Cells by Activating the JNK Signaling Pathway. Oncol. Lett. 19, 255-260. doi:10.3892/ol.2019.11104

Shang, C.-h., Zhang, Q.-q., and Zhou, J.-h. (2016). Oridonin Inhibits Cell Proliferation and Induces Apoptosis in Rheumatoid Arthritis Fibroblastlike Synoviocytes. Inflammation 39, 873-880. doi:10.1007/s10753-0160318-2

Shi, M., Deng, Y., Yu, H., Xu, L., Shi, C., Chen, J., et al. (2019). Protective Effects of Oridonin on Acute Liver Injury via Impeding Posttranslational Modifications of Interleukin-1 Receptor-Associated Kinase 4 (Irak4) in the Toll-like Receptor 4 (Tlr4) Signaling Pathway. Mediators Inflamm. 2019, 1-11. doi:10.1155/2019/ 7634761

Shi, M., Lu, X.-J., Zhang, J., Diao, H., Li, G., Xu, L., et al. (2016). Oridonin, a Novel Lysine Acetyltransferases Inhibitor, Inhibits Proliferation and Induces Apoptosis in Gastric Cancer Cells through P53- and Caspase-3-Mediated Mechanisms. Oncotarget 7, 22623-22631. doi:10.18632/oncotarget.8033

Spirin, P., Lebedev, T., Orlova, N., Morozov, A., Poymenova, N., Dmitriev, S. E., et al. (2017). Synergistic Suppression of T(8;21)-Positive Leukemia Cell Growth by Combining Oridonin and Mapk1/erk2 Inhibitors. Oncotarget 8, 56991-57002. doi:10.18632/oncotarget.18503

Sun, Q., He, M., Zhang, M., Zeng, S., Chen, L., Zhou, L., et al. (2020a). Ursolic Acid: A Systematic Review of its Pharmacology, Toxicity and Rethink on its Pharmacokinetics Based on PK-PD Model. Fitoterapia 147, 104735. doi:10.1016/j.fitote.2020.104735

Sun, Q., Xie, L., Song, J., and Li, X. (2020b). Evodiamine: A Review of its Pharmacology, Toxicity, Pharmacokinetics and Preparation Researches. J. Ethnopharmacology 262, 113164. doi:10.1016/j.jep.2020.113164

Sun, Y., Jiang, X., Lu, Y., Zhu, J., Yu, L., Ma, B., et al. (2018). Oridonin Prevents Epithelial-Mesenchymal Transition and TGF- $\beta 1$-Induced EpithelialMesenchymal Transition by Inhibiting TGF- $\beta 1 / \mathrm{Smad} 2 / 3$ in Osteosarcoma. Chemico-Biological Interactions 296, 57-64. doi:10.1016/j.cbi.2018.09.013

Sun, Z., Han, Q., Duan, L., Yuan, Q., and Wang, H. (2018). Oridonin Increases Anticancer Effects of Lentinan in Hepg2 Human Hepatoblastoma Cells. Oncol. Lett. 15, 1999-2005. doi:10.3892/ol.2017.7485

Tian, L., Sheng, D., Li, Q., Guo, C., and Zhu, G. (2019). Preliminary Safety Assessment of Oridonin in Zebrafish. Pharm. Biol. 57, 632-640. doi:10.1080/13880209.2019.1662457

Tian, L., Xie, K., Sheng, D., Wan, X., and Zhu, G. (2017). Antiangiogenic Effects of Oridonin. BMC Complement. Altern. Med. 17, 192. doi:10.1186/s12906-017-1706-3

Tian, T., Jin, Y., Ma, Y., Xie, W., Xu, H., Zhang, K., et al. (2015). Identification of Metabolites of Oridonin in Rats with a Single Run on Uplc-Triple-Tof-Ms/ms System Based on Multiple Mass Defect Filter Data Acquisition and Multiple Data Processing Techniques. J. Chromatogr. B 1006, 80-92. doi:10.1016/ j.jchromb.2015.10.006

Tiwari, R. V., Parajuli, P., and Sylvester, P. W. (2015). Synergistic Anticancer Effects of Combined $\gamma$-tocotrienol and Oridonin Treatment Is Associated with the Induction of Autophagy. Mol. Cel Biochem 408, 123-137. doi:10.1007/ s11010-015-2488-x

Vasaturo, M., Cotugno, R., Fiengo, L., Vinegoni, C., Dal Piaz, F., and De Tommasi, N. (2018). The Anti-tumor Diterpene Oridonin Is a Direct Inhibitor of Nucleolin in Cancer Cells. Sci. Rep. 8, 16735. doi:10.1038/s41598-018-35088-x

Wang, B., Shen, C., Li, Y., Zhang, T., Huang, H., Ren, J., et al. (2019). Oridonin Overcomes the Gemcitabine Resistant Panc-1/gem Cells by Regulating Gst Pi and Lrp/1 Erk/jnk Signalling. Onco Targets Ther. 12, 5751-5765. doi:10.2147/Ott.S208924

Wang, J., Li, F., Ding, J., Tian, G., Jiang, M., Gao, Z., et al. (2016). Investigation of the Anti-asthmatic Activity of Oridonin on a Mouse Model of Asthma. Mol. Med. Rep. 14, 2000-2006. doi:10.3892/mmr.2016.5485

Wang, S., Yang, H., Yu, L., Jin, J., Qian, L., Zhao, H., et al. (2014). Oridonin Attenuates A $\beta 1-42$-Induced Neuroinflammation and Inhibits NF-кB Pathway. Plos One 9, e104745. doi:10.1371/journal.pone.0104745
Wang, S., Yu, L., Yang, H., Li, C., Hui, Z., Xu, Y., et al. (2016). Oridonin Attenuates Synaptic Loss and Cognitive Deficits in an A $\beta 1$-42-Induced Mouse Model of Alzheimer's Disease. Plos One 11, e0151397-16. doi:10.1371/journal.pone.0151397

Wang, S., Zhang, Y., Saas, P., Wang, H., Xu, Y., Chen, K., et al. (2015). Oridonin's Therapeutic Effect: Suppressing Th1/Th17 Simultaneously in a Mouse Model of Crohn's Disease. J. Gastroenterol. Hepatol. 30, 504-512. doi:10.1111/jgh.12710

Wang, Y., and Zhu, Z. (2019). Oridonin Inhibits Metastasis of Human Ovarian Cancer Cells by Suppressing the Mtor Pathway. aoms 15, 1017-1027. doi:10.5114/aoms.2018.77068

Wen, F., Zhuge, W., Wang, J., Lu, X., You, R., Liu, L., et al. (2020). Oridonin Prevents Insulin Resistance-Mediated Cognitive Disorder through Pten/akt Pathway and Autophagy in Minimal Hepatic Encephalopathy. J. Cel Mol Med 24, 61-78. doi:10.1111/jcmm.14546

Wu, H., Zhu, G. H., and Su, Y. Z. (2020). Oridonin Improves the Sensitivity of Multiple Myeloma Cells to Bortezomib through the Pten/pi3k/akt Pathway. Curr. Top. Nutraceut R. 18, 292-296. doi:10.37290/ctnr2641-452X.18:292-296

Wu, Q.-X., Yuan, S.-X., Ren, C.-M., Yu, Y., Sun, W.-J., He, B.-C., et al. (2016). Oridonin Upregulates Pten through Activating P38 Mapk and Inhibits Proliferation in Human colon Cancer Cells. Oncol. Rep. 35, 3341-3348. doi:10.3892/or.2016.4735

Wu, Q. J., Zheng, X. C., Wang, T., and Zhang, T. Y. (2018a). Effect of Dietary Oridonin Supplementation on Growth Performance, Gut Health, and Immune Response of Broilers Infected with salmonella Pullorum. Ir Vet. J. 71, 1-6. doi:10.1186/s13620-018-0128-y

Wu, Q. J., Zheng, X. C., Wang, T., and Zhang, T. Y. (2018b). Effects of Dietary Supplementation with Oridonin on the Growth Performance, Relative Organ Weight, Lymphocyte Proliferation, and Cytokine Concentration in Broiler Chickens. Bmc Vet. Res. 14, 34. doi:10.1186/s12917-018-1359-6

Wu, Q. J., Zheng, X. C., Wang, T., and Zhang, T. Y. (2018c). Effects of Oridonin on Immune Cells, Th1/th2 Balance and the Expression of Blys in the Spleens of Broiler Chickens Challenged with salmonella Pullorum. Res. Vet. Sci. 119, 262-267. doi:10.1016/j.rvsc.2018.07.008

Xia, S., Zhang, X., Li, C., and Guan, H. (2017). Oridonin Inhibits Breast Cancer Growth and Metastasis through Blocking the Notch Signaling. Saudi Pharm. J. 25, 638-643. doi:10.1016/j.jsps.2017.04.037

Xiao, X., He, Z., Cao, W., Cai, F., Zhang, L., Huang, Q., et al. (2016). Oridonin Inhibits Gefitinib-Resistant Lung Cancer Cells by Suppressing Egfr/erk/mmp12 and Cip2a/akt Signaling Pathways. Int. J. Oncol. 48, 2608-2618. doi:10.3892/ ijo.2016.3488

Xu, L., Bi, Y., Xu, Y., Zhang, Z., Xu, W., Zhang, S., et al. (2020). Oridonin Inhibits the Migration and Epithelial-to-mesenchymal Transition of Small Cell Lung Cancer Cells by Suppressing FAK-ERK1/2 Signalling Pathway. J. Cel Mol Med 24, 4480-4493. doi:10.1111/jcmm.15106

Xu, L., Li, L., Zhang, C.-Y., Schluesener, H., and Zhang, Z.-Y. (2019). Natural Diterpenoid Oridonin Ameliorates Experimental Autoimmune Neuritis by Promoting Anti-inflammatory Macrophages through Blocking Notch Pathway. Front. Neurosci. 13, 272. doi:10.3389/fnins.2019.00272

Xu, M., Wan, C.-x., Huang, S.-h., Wang, H.-b., Fan, D., Wu, H.-M., et al. (2019). Oridonin Protects against Cardiac Hypertrophy by Promoting P21-Related Autophagy. Cell Death Dis 10, 403. doi:10.1038/s41419-019-1617-y

Xu, T., Jin, F., Wu, K., Ye, Z., Li, N., and Li, N. (2017). Oridonin Enhances In Vitro Anticancer Effects of Lentinan in SMMC-7721 Human Hepatoma Cells through Apoptotic Genes. Exp. Ther. Med. 14, 5129-5134. doi:10.3892/ etm.2017.5168

Xu, Z.-Z., Fu, W.-B., Jin, Z., Guo, P., Wang, W.-F., and Li, J.-M. (2016). Reactive Oxygen Species Mediate Oridonin-Induced Apoptosis through DNA Damage Response and Activation of Jnk Pathway in Diffuse Large B Cell Lymphoma. Leuk. Lymphoma 57, 888-898. doi:10.3109/10428194.2015.1061127

Yan, Y., Tan, R.-z., Liu, P., Li, J.-c., Zhong, X., Liao, Y., et al. (2020). Oridonin Alleviates Iri-Induced Kidney Injury by Inhibiting Inflammatory Response of Macrophages via Akt-Related Pathways. Med. Sci. Monit. 26, e921114. doi:10.12659/MSM.921114

Yang, H., Gao, Y., Fan, X., Liu, X., Peng, L., Ci, X. X., et al. (2019a). Oridonin Sensitizes Cisplatin-Induced Apoptosis via Ampk/akt/mtor-dependent Autophagosome Accumulation in A549 Cells. Front. Oncol. 9, 769. doi:10.3389/fonc.2019.00769

Yang, H., Huang, J., Gao, Y., Wen, Z., Peng, L., and Ci, X. (2020). Oridonin Attenuates Carrageenan-Induced Pleurisy via Activation of the KEAP-1/Nrf2 
Pathway and Inhibition of the TXNIP/NLRP3 and NF-кB Pathway in Mice. Inflammopharmacol 28, 513-523. doi:10.1007/s10787-019-00644-y

Yang, H., Lv, H., Li, H., Ci, X., and Peng, L. (2019b). Oridonin Protects LPSInduced Acute Lung Injury by Modulating Nrf2-Mediated Oxidative Stress and Nrf2-independent NLRP3 and NF-kB Pathways. Cell Commun Signal 17, 62. doi:10.1186/s12964-019-0366-y

Yang, I.-H., Shin, J.-A., Lee, K.-E., Kim, J., Cho, N.-P., and Cho, S.-D. (2017). Oridonin Induces Apoptosis in Human Oral Cancer Cells via Phosphorylation of Histone H2ax. Eur. J. Oral Sci. 125, 438-443. doi:10.1111/eos.12387

Yang, Y.-C., Lin, P.-H., and Wei, M.-C. (2017). Production of Oridonin-Rich Extracts fromRabdosia Rubescensusing Hyphenated Ultrasound-Assisted Supercritical Carbon Dioxide Extraction. J. Sci. Food Agric. 97, 3323-3332. doi:10.1002/jsfa. 8182

Yao, Z., Xie, F., Li, M., Liang, Z., Xu, W., Yang, J., et al. (2017). Oridonin Induces Autophagy via Inhibition of Glucose Metabolism in P53-Mutated Colorectal Cancer Cells. Cel Death Dis 8, e2633. doi:10.1038/cddis.2017.35

Yu, T., Xie, W., and Sun, Y. (2019). Oridonin Inhibits LPS-Induced Inflammation in Human Gingival Fibroblasts by Activating PPAR $\gamma$. Int. Immunopharmacology 72, 301-307. doi:10.1016/j.intimp.2019.04.006

Yuan, Z., Ouyang, P., Gu, K., Rehman, T., Zhang, T., Yin, Z., et al. (2019). The Antibacterial Mechanism of Oridonin against Methicillin-Resistant staphylococcus Aureus (Mrsa). Pharm. Biol. 57, 710-716. doi:10.1080/ 13880209.2019.1674342

Zang, K.-h., Shao, Y.-y., Zuo, X., Rao, Z., and Qin, H.-y. (2016). Oridonin Alleviates Visceral Hyperalgesia in a Rat Model of Postinflammatory Irritable Bowel Syndrome: Role of Colonic Enterochromaffin Cell and Serotonin Availability. J. Med. Food 19, 586-592. doi:10.1089/jmf.2015.3595

Zhang D., D., Zhou, Q., Huang, D., He, L., Zhang, H., Hu, B., et al. (2019). Ros/jnk/ c-jun axis Is Involved in Oridonin-Induced Caspase-dependent Apoptosis in Human Colorectal Cancer Cells. Biochem. Biophysical Res. Commun. 513, 594-601. doi:10.1016/j.bbrc.2019.04.011

Zhang J., J., Zhou, Y., Sun, Y., Yan, H., Han, W., Wang, X., et al. (2019). Beneficial Effects of Oridonin on Myocardial Ischemia/reperfusion Injury: Insight Gained by Metabolomic Approaches. Eur. J. Pharmacol. 861, 172587. doi:10.1016/ j.ejphar.2019.172587

Zhang W., W., Lu, Y., Zhen, T., Chen, X., Zhang, M., Liu, P., et al. (2019). Homoharringtonine Synergy with Oridonin in Treatment of $\mathrm{T}(8 ; 21)$ Acute Myeloid Leukemia. Front. Med. 13, 388-397. doi:10.1007/s11684-018-0624-1

Zhang, Y.-w., Bao, M.-h., Hu, L., Qu, Q., and Zhou, H.-h. (2014a). Dose-response of Oridonin on Hepatic Cytochromes P450 Mrna Expression and Activities in Mice. J. Ethnopharmacology 155, 714-720. doi:10.1016/j.jep.2014.06.009

Zhang, Y.-w., Zheng, X.-w., Liu, Y.-j., Fang, L., Pan, Z.-f., Bao, M.-h., et al. (2018b). Effect of Oridonin on Cytochrome P450 Expression and Activities in Heparg Cell. Pharmacology 101, 246-254. doi:10.1159/000486600

Zhang, Y. W., Bao, M. H., Wang, G., Qu, Q., and Zhou, H. H. (2014b). Induction of Human Cyp3a4 by Huperzine a, Ligustrazine and Oridonin through Pregnane X Receptor-Mediated Pathways. Pharmazie 69, 532-536. doi:10.1691/ ph.2014.3950

Zhang, Y., Wang, S., Dai, M., Nai, J., Zhu, L., and Sheng, H. (2020). Solubility and Bioavailability Enhancement of Oridonin: A Review. Molecules 25, 332. doi:10.3390/molecules25020332

Zhang, Y. W., Bao, M. H., Lou, X. Y., Cheng, Y., Yu, J., and Zhou, H. H. (2018a). Effects of Oridonin on Hepatic Cytochrome P450 Expression and Activities in Pxr-Humanized Mice. Biol. Pharm. Bull. 41, 707-712.
Zhang, Z. Y., Daniels, R., and Schluesener, H. J. (2013). Oridonin Ameliorates Neuropathological Changes and Behavioural Deficits in a Mouse Model of Cerebral Amyloidosis. J. Cel. Mol. Med. 17, 1566-1576. doi:10.1111/jcmm.12124

Zhao, G., Zhang, T., Ma, X., Jiang, K., Wu, H., Qiu, C., et al. (2017). Oridonin Attenuates the Release of Pro-inflammatory Cytokines in LipopolysaccharideInduced raw264.7 Cells and Acute Lung Injury. Oncotarget 8, 68153-68164. doi:10.18632/oncotarget.19249

Zhao, J., Zhang, M., He, P., Zhao, J., Chen, Y., Qi, J., et al. (2017). Proteomic Analysis of Oridonin-Induced Apoptosis in Multiple Myeloma Cells. Mol. Med. Rep. 15, 1807-1815. doi:10.3892/mmr.2017.6213

Zhao, Y.-J., Lv, H., Xu, P.-B., Zhu, M.-M., Liu, Y., Miao, C.-H., et al. (2016). Protective Effects of Oridonin on the Sepsis in Mice. Kaohsiung J. Med. Sci. 32, 452-457. doi:10.1016/j.kjms.2016.07.013

Zhao, Y., and Xia, H. (2019). Oridonin Elevates Sensitivity of Ovarian Carcinoma Cells to Cisplatin via Suppressing Cisplatin-Mediated Autophagy. Life Sci. 233, 116709. doi:10.1016/j.lfs.2019.116709

Zheng, M., Zhu, Z., Zhao, Y., Yao, D., Wu, M., and Sun, G. (2017). Oridonin Promotes G2/m Arrest in A549 Cells by Facilitating Atm Activation. Mol. Med. Rep. 15, 375-379. doi:10.3892/mmr.2016.6008

Zheng, W., Zhou, C.-Y., Zhu, X.-Q., Wang, X.-J., Li, Z.-Y., Chen, X.-C., et al. (2018). Oridonin Enhances the Cytotoxicity of 5 -fu in Renal Carcinoma Cells by Inducting Necroptotic Death. Biomed. Pharmacother. 106, 175-182. doi:10.1016/j.biopha.2018.06.111

Zheng, X. C., Wu, Q. J., Song, Z. H., Zhang, H., Zhang, J. F., Zhang, L. L., et al. (2016). Effects of Oridonin on Growth Performance and Oxidative Stress in Broilers Challenged with Lipopolysaccharide. Poult. Sci. 95, 2281-2289. doi:10.3382/ps/pew161

Zhou, L., Sun, L., Wu, H., Zhang, L., Chen, M., Liu, J., et al. (2013). Oridonin Ameliorates Lupus-like Symptoms of Mrllpr/lpr Mice by Inhibition of B-Cell Activating Factor (Baff). Eur. J. Pharmacol. 715, 230-237. doi:10.1016/ j.ejphar.2013.05.016

Zhou, M., Yi, Y., and Hong, L. (2019). Oridonin Ameliorates LipopolysaccharideInduced Endometritis in Mice via Inhibition of the TLR-4/NF-kBpathway. Inflammation 42, 81-90. doi:10.1007/s10753-018-0874-8

Zhu, H. Q., Zhang, C., Guo, Z. Y., Yang, J. M., Guo, J. H., Chen, C., et al. (2019). Oridonin Induces Mdm2-p60 to Promote P53-mediated Apoptosis and Cell Cycle Arrest in Neuroblastoma. Cancer Med. 8, 5313-5326. doi:10.1002/ cam4.2393

Zou, B.-h., Tan, Y.-h., Deng, W.-d., Zheng, J.-h., Yang, Q., Ke, M.-h., et al. (2020). Oridonin Ameliorates Inflammation-Induced Bone Loss in Mice via Suppressing Dc-Stamp Expression. Acta Pharmacol. Sin 42, 744-754. doi:10.1038/s41401-020-0477-4

Conflict of Interest: The authors declare that the research was conducted in the absence of any commercial or financial relationships that could be construed as a potential conflict of interest.

Copyright $\odot 2021 \mathrm{Li}$, Zhang, Ma, Xie and Huang. This is an open-access article distributed under the terms of the Creative Commons Attribution License (CC BY). The use, distribution or reproduction in other forums is permitted, provided the original author(s) and the copyright owner(s) are credited and that the original publication in this journal is cited, in accordance with accepted academic practice. No use, distribution or reproduction is permitted which does not comply with these terms. 